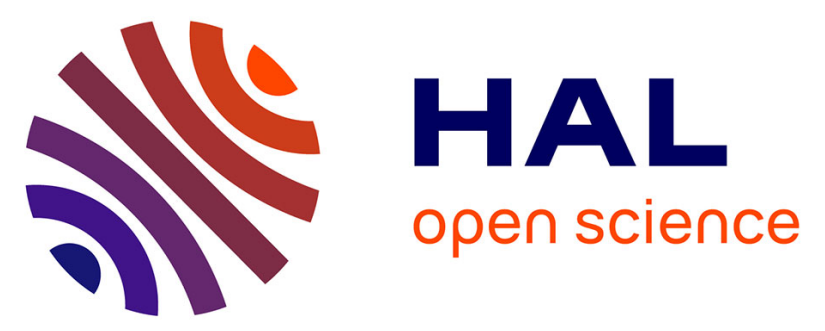

\title{
Natural mineralized fractures from the Montney-Doig unconventional reservoirs (Western Canada Sedimentary Basin): Timing and controlling factors
}

Marta Gasparrini, Olivier Lacombe, Sébastien Rohais, Belkacemi Mohammed, Tristan Euzen

\section{To cite this version:}

Marta Gasparrini, Olivier Lacombe, Sébastien Rohais, Belkacemi Mohammed, Tristan Euzen. Natural mineralized fractures from the Montney-Doig unconventional reservoirs (Western Canada Sedimentary Basin): Timing and controlling factors. Marine and Petroleum Geology, 2021, 124, pp.104826. 10.1016/j.marpetgeo.2020.104826 . insu-03097687

\section{HAL Id: insu-03097687 https://hal-insu.archives-ouvertes.fr/insu-03097687}

Submitted on 5 Jan 2021

HAL is a multi-disciplinary open access archive for the deposit and dissemination of scientific research documents, whether they are published or not. The documents may come from teaching and research institutions in France or abroad, or from public or private research centers.
L'archive ouverte pluridisciplinaire HAL, est destinée au dépôt et à la diffusion de documents scientifiques de niveau recherche, publiés ou non, émanant des établissements d'enseignement et de recherche français ou étrangers, des laboratoires publics ou privés. 


\section{Journal Pre-proof}

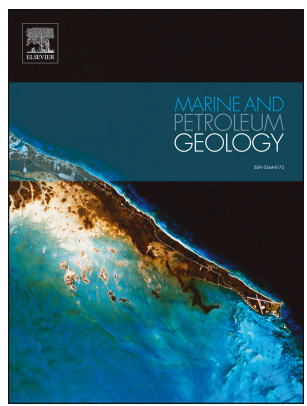

Natural mineralized fractures from the Montney-Doig unconventional reservoirs

(Western Canada sedimentary basin): Timing and controlling factors

Marta Gasparrini, Olivier Lacombe, Sébastien Rohais, Moh Belkacemi, Tristan Euzen

PII:

S0264-8172(20)30609-7

DOI: $\quad$ https://doi.org/10.1016/j.marpetgeo.2020.104826

Reference: JMPG 104826

To appear in: Marine and Petroleum Geology

Received Date: 5 August 2020

Revised Date: 10 November 2020

Accepted Date: 16 November 2020

Please cite this article as: Gasparrini, M., Lacombe, O., Rohais, Sé., Belkacemi, M., Euzen, T., Natural mineralized fractures from the Montney-Doig unconventional reservoirs (Western Canada sedimentary basin): Timing and controlling factors, Marine and Petroleum Geology (2020), doi: https:// doi.org/10.1016/j.marpetgeo.2020.104826.

This is a PDF file of an article that has undergone enhancements after acceptance, such as the addition of a cover page and metadata, and formatting for readability, but it is not yet the definitive version of record. This version will undergo additional copyediting, typesetting and review before it is published in its final form, but we are providing this version to give early visibility of the article. Please note that, during the production process, errors may be discovered which could affect the content, and all legal disclaimers that apply to the journal pertain.

(C) 2020 Published by Elsevier Ltd. 


\section{CREdiT Author Statement}

Marta Gasparrini : Conceptualization, Writing - Original Draft, Supervision, Investigation, Visualization

Olivier Lacombe: Writing - Original Draft, Supervision

Sébastien Rohais: Writing - Original Draft, Visualization

Moh Belkacemi: Investigation, Visualization

Tristan Euzen: Writing - Review \& Editing, Resources 
1 Natural mineralized fractures from the Montney-Doig

2 unconventional reservoirs (Western Canada Sedimentary Basin):

3 timing and controlling factors

Marta Gasparrini ${ }^{1,2^{*}}$, Olivier Lacombe ${ }^{3}$, Sébastien Rohais ${ }^{2}$, Moh Belkacemi $^{2,3}$, Tristan Euzen $^{4}$

${ }^{1}$ University of Milan, Earth Sciences Department, via Mangiagalli 34, 20133 Milan, Italy

${ }^{2}$ IFP Energies nouvelles, 1-4 avenue du Bois-Préau, 92852 Rueil-Malmaison, France

${ }^{3}$ Sorbonne Université , Institut des Sciences de la Terre de Paris - ISTeP, CNRS-INSU, Paris, France

${ }^{4}$ IFP Technologies (Canada) Inc., Calgary, Canada

*Corresponding author (marta.gasparrini@unimi.it)

ABSTRACT

Characterizing the origin of natural fractures in organic-rich fine-grained deposits is key to constraining permeability evolution in these potential source rocks and tight reservoirs, as well as to assess the hydraulic connectivity of the fluid systems in which they develop. 
The results demonstrate the relevance and usefulness of such multidisciplinary studies to

gather insights on: 1) the lithology-related factors controlling fracture occurrence; 2) the timing of fracture opening and the origin of the circulating paleo-fluids; 3) the openness of the fluid system through time.

More specifically, host-rock facies (particularly grain size) and vertical facies changes appear to be the leading factors controlling fracture occurrence. A less relevant role was played by the occurrence of diagenetic carbonates, while TOC possibly did not control fracture occurrence.

Three generations of calcite cemented fractures were identified. Vertical fractures (first generation) post-dated the onset of oil generation (Late Cretaceous). Horizontal, bedding-parallel fractures (second generation) post-dated the onset of gas generation and possibly opened close to maximum burial, corresponding to peak hydrocarbon $\left(\mathrm{CH}_{4}\right)$ generation (Late Cretaceous - Early Paleogene). Vertical fractures (third generation) post-dated the horizontal ones and opened during basin uplift (Middle to Late Paleogene).

The consistent petrographic and geochemical features of all the calcite cements point to parent fluids in equilibrium with the host-rock lithologies, that possibly behaved as a closed hydraulic system during Late Cretaceous to Paleogene time; this would support the hypothesis that, at least in the portion of the basin investigated, the Montney Fm also acted as source rock of the unconventional system.

Keywords: Montney-Doig, fracture diagenesis, paleo-fluids, source rocks, tight reservoirs

\section{INTRODUCTION}

Fine-grained siliciclastic deposits like shales and siltstones (i.e. mudrocks, sensu Lazar et al., 2015) largely contribute to the filling of sedimentary basins and most commonly constitute low- 
permeability rock units, unless they are affected by fracturing processes. Natural fractures commonly occur in mudrocks (e.g. Gale et al., 2014; Ukar et al., 2017; Hooker et al., 2019), though their occurrence and the extent to which they enhance the overall rock permeability still remain poorly constrained (Dewhurst et al. 1999).

The development and sealing of natural fractures within organic-rich mudrock successions have received great attention since the interest of exploration in unconventional gas and oil plays rose, particularly in North America (Curtis, 2002; Gale et al., 2007; Engelder et al., 2009). These plays encompass a variety of low-permeability reservoirs that require hydraulic fracturing to be commercially productive and are generally found within or in close association with source rock intervals. The rising interest for unconventional oil and gas plays revealed that source rocks in these settings may also represent the reservoirs of $\mathrm{HC}$ accumulations which may be generated in-situ or may have migrated from external sources. Discriminating among the possible behaviors (open versus closed system) of organic-rich mudrock successions during burial and thermal maturation in such plays is relevant to, among others, better assess the amounts of ultimate $\mathrm{HC}$ in place (e.g. Jarvie et al., 2007).

On the other hand, characterizing the processes that cause natural fractures in fine-grained organic-rich deposits is crucial to better understand permeability evolution within these potential tight reservoirs (Gale and Holder, 2010; Cobbold et al., 2013; Gasparrini et al., 2014). Several mechanisms may act independently or in combination to cause fracture growth such as the conversion of organic matter in HC (Spencer, 1987; Ozkaya, 1988; Vernik, 1994; Jochum et al., 1995; Marquez and Montjoy, 1996; Zanella et al., 2014; Meng et al., 2017), the build-up of tectonic stress at different moments of the basin history (Ukar et al., 2017; Hooker et al., 2019), as well as the occurrence of specific diagenetic processes (e.g. Van de Kamp, 2008; Gasparrini et al., 2014; Hooker et al., 2017a). Regardless of the mechanisms, mineral cementation may accompany fracturing to form mineralized fracture (i.e. veins), which investigation may help discriminating fracture growth timing and/or genetic mechanism. This may be relevant for predicting evolution of hydraulic 
connectivity through time and joint relationships with organic matter maturation that can provide constraints to calibrate numerical models for the exploration and production of unconventional resources (e.g. Sassi et al., 2012; Romero-Sarmiento et al., 2013).

Additionally, the localization of the fractured intervals in the organic-rich mudrocks may be controlled by different factors capable of affecting the mechanical properties of the rocks (e.g. Young's modulus, Poisson's ratios). Primary sedimentary features of these deposits (e.g. grain size, total organic carbon (TOC), mineralogy), their diagenetic modifications during burial (e.g. cementations, replacements) and the vertical heterogeneities of the succession (e.g. bed thickness, facies stacking pattern, fissility), may control mechanical properties and therefore the localization of fractures and consequently, the rock response to hydraulic fracturing (e.g. Vishkai et al., 2017). However, consensus is not reached in literature on the role of these different factors (Engelder and Peacock, 2001; Rijken and Cooke, 2001; Peacock and Mann, 2005; Wang and Gale, 2009; Gale et al. 2014; Wang et al., 2016; Ilgen et al., 2017; Hooker et al., 2020; Peng et al., 2020) and this is especially true when referring to the coarser mudrock end-member, i.e. the siltstones (e.g. Vaisblat et al., 2017a, 2019; Chatellier et al., 2018).

For the different reasons mentioned above, characterizing the factors controlling the occurrence of natural fractures in organic-rich fine-grained deposits, as well as framing the timing and mechanism of fracturing within the local geological evolution, is key to evaluate permeability and fluid pathway potential through time of these rocks, and hence their present reservoir properties and sealing capacity.

Our study focuses on the mudrocks from the Lower-Middle Triassic Montney-Doig Fms in the Western Canadian Sedimentary Basin (WCSB). More specifically, the Montney Fm is one of the largest economically feasible resource plays and is classified as an unconventional tight oil and gas siltstone reservoir (Davies et al., 1997; Moslow, 2000; Euzen et al., 2018). Since the failure mechanics of such rocks is poorly understood and seldom incorporated in hydraulic fracturing or geomechanical models, this formation has received much attention in terms of characterization of physical and 
mechanical properties from laboratory tests (Ghanizadeh et al., 2015a,b; Vishkai et al., 2017; Vaisblat et al., 2017a, 2019; Riazi et al., 2017; McKean and Priest, 2019). Geometric features and structural fabrics of fractures in the Montney Fm have been investigated from well cores by few authors (Davies et al., 2014; Gillen et al., 2019). Surprisingly however, poor attention has been paid to the characterization of the distribution (in space and time) of natural mineralized fractures.

In an attempt at shedding new light onto these last issues, we investigated mineralized fractures occurring in the Montney-Doig lithologies from two well cores located in British Columbia by applying a multidisciplinary approach (including sedimentology, Rock-Eval pyrolysis, petrography, O-C-Sr isotope geochemistry and fluid inclusion microthermometry) to host-rocks and fracture filling calcites. The main purposes of this survey were: 1 ) to constrain the factors controlling fracture occurrence in relation with the host-rock properties, 2) to define the relative timing of fracture opening in the framework of the burial and geodynamic history of the WCSB, and 3) to assess the origin of the circulating paleo-waters precipitating the fracture-sealing calcites, in order to gain insight on the fluid system openness through time.

\section{GEOLOGICAL SETTING}

The WCSB is a complex, polyphase basin system the evolution of which includes a succession of rift and passive-margin basins, intracratonic basins, and foreland basin (Mossop and Shetsen, 1994). A first collisional pro-foreland developed during the Permian, that was followed by a second stage of foreland (retro-foreland) as early as the the Triassic (Ferri and Zonneveld, 2008; Golding et al., 2015; Rohais et al., 2018). Then, eastward subduction of the Farallon plate and subsequent collision of terranes along the western margin of North America during the Middle-Late Jurassic gave birth to the North American Cordillera and its associated retro-foreland basin (Price, 1994; Gillespie and Heller, 1995; DeCelles, 2004; Miall et al., 2008; Fuentes et al., 2011). Sediments were deposited in this retro-foreland basin until the Eocene (Dawson et al., 1994), forming an eastward- thinning 
wedge that is $\sim 5-6 \mathrm{~km}$ thick in front of the present-day Canadian Rocky Mountains fold-and-thrust belt, and pinches out onto the Canadian Shield (Price, 1994; Wright et al., 1994; Tufano and Pietras, 2017).

The history of the WCSB has a close link to the tectonic evolution of the nearby Rocky Mountains. On the basis of radiometric age dating of gouges from major thrusts located in the Rocky Mountains and Foothills of Alberta, Pană and van der Pluijm (2015) showed that the eastward propagation of the southern Canadian Rocky Mountains fold-and-thrust belt occurred in sequence through four orogenic pulses (separated by periods of tectonic quiescence) that correspond to depositional patterns in the adjacent foreland basin. The development of the first clastic wedge in the basin was partly coeval with the initiation of the westernmost thrusts that moved during a first pulse (Late Jurassic, 163-145 Ma) in relation to the onset of thin-skinned deformation from Jurassic terrane accretion. Development of Cenomanian deltaic deposits in the basin was contemporaneous with a second thrusting pulse (mid-Cretaceous, 103-99 Ma), and the last major transgression in the southern Alberta foreland was related to a third pulse of tectonic loading (Late Cretaceous, 74-75 Ma). The outermost thrusts to the east (e.g. the McConnell thrust) moved during the last pulse (early Eocene, 52-54 Ma) and witnessed the last phase of regional contraction which triggered the accumulation of large volumes of entirely continental deposits in the foreland basin. These thrusting events presumably occurred under a NE-SW to ENE-WSW direction of the maximum principal stress $\sigma 1$ associated to a compressional or transpressional stress regime, as revealed by paleostress analyses in the Rocky Mountains fold-and-thrust belt at the latitude of Calgary (Vandeginste et al. 2012). The stress regime later changed to extensional/transtensional in type during the Eocene. Within the WCSB, the Lower-Middle Triassic deposits of interest belong to the Montney-Doig Fms (Fig. 1) and consist primarily of fine-grained sandstones, siltstones and shales with locally occurring sandy, bioclastic packstone and grainstone beds that were accumulated in a large variety of marine (deep turbidite) to marginal-marine environments (Armitage 1962; Davies 1997; Davies et al. 1997; Zonneveld et al. 1997, 2001; Dixon 2000; Orchard and Zonneveld 2009; Crombez et al., 2016; 
Moslow et al., 2016, 2018; Furlong et al. 2018a; Davies et al., 2018; Euzen et al., 2018 ; Zonneveld and Moslow, 2018). This sedimentary succession was initially sub-divided into three formations, from older to younger: the Montney, Doig and Halfway, with a recent update between the Montney and Doig Fms corresponding to the localized Sunset Prairie Fm (Furlong et al. 2018b). The Lower-Middle Triassic deposits are preserved in between the Permian Belloy Fm and the Late Triassic Charlie Lake Fm or the regional pre-Cretaceous erosional unconformity. The Lower-Middle Triassic deposits were affected by reactivation of inherited structures from both the Paleozoic Peace River Arch (PRA) collapse, and the older Hay River Shear Zone (HRSZ) (Fig.1; Davies, 1997; Peirce et al., 2001).

The synthetic stratigraphic architecture of the Montney-Doig interval (Crombez et al., 2019) is presented in figure 2. Four sequence boundaries are presented, delimiting four stratigraphic sequences. The first three (sequences 1-3) belong the Montney Fm, and the last (sequence 4) encompasses the Doig and Halfway Fms. This study is mainly focused on the three third order sequences of the Montney Fm (sequences 1-3), and on the basal part of the sequence 4 including the Doig Phosphatic Member (Doig Fm).

Triassic source rocks only reach maturity in the western part of the basin and become overmature close to the Cordillera deformation front. The peak $\mathrm{HC}$ generation ranges from approximately $100 \mathrm{Ma}$ (mid-Albian) to $60 \mathrm{Ma}$ (Paleocene) for the Doig Fm based on 1D basin modeling (Ness, 2001). According to Ness (2001), the timing of HC generation for the Montney Fm is more complex with possible early generation between 120 and $130 \mathrm{Ma}$, and additional later oil and gas generation during burial at approximately 100 to 110 Ma. At basin scale, secondary gas generation probably started at 90-100 Ma and at about $70 \mathrm{Ma}$ in the studied sector (Ness, 2001). More recently, Ducros et al. (2017), based on 2D petroleum basin modeling, suggested that the Montney Fm started to generate hydrocarbon in this western part of the basin during the Late Cretaceous (88,5 Ma). These authors also suggested that the Montney Fm reached the maximum 
transformation rate just before reaching the maximum burial, which was followed by a major exhumation and erosional event starting in the Early Paleogene.

\section{MATERIAL AND METHODS}

Two non-oriented well cores from British Columbia (ca. $70 \mathrm{Km}$ North-West of Fort St. John; Fig. 1A) intercepting the Montney and Doig Fms were investigated. They correspond to 00/16-17083-25W6/0 and to 00/12-36-083-25W6/0, vertical wells (BC Oil \& Gas Commission), hereafter referred as 16-17 and 12-36, respectively. The wells are located ca. $70 \mathrm{~km}$ North-West of Fort St. John and between the HRSZ and the inherited structure from the Paleozoic PRA collapse (Fig. 1A). They are located $7.2 \mathrm{~km}$ from each other and based on available basin models (see later in this section) have experienced a similar burial and thermal history. In particular, the 16-17 continuous well core includes the entire section of the Montney Fm (sequences 1, 2 and 3; Crombez et al.,2016) and the basal part of the Doig Fm, whereas the 12-36 well core is composed of three discontinuous cores of the Montney Fm only for which mineralogical data for two of them (core 1 and core 3 ) are available from the British Columbia Oil \& Gas Commission public database.

Sedimentological logs for the two well cores were described at the 1:50 scale by some of the co-authors in the frame of a PhD thesis (Crombez, 2016). Wire-log data for the two well cores were available from the British Columbia Oil \& Gas Commission. Investigated well core depth goes from 2531 to $2233 \mathrm{~m}$ for well $16-17$ and from 2369 to $2088 \mathrm{~m}$ for well 12-36. Lithology, sedimentary structures, textures and paleontological contents allowed characterizing different macro-facies. Occurrence and orientation of fractures was also reported on the logs (Fig. 3). The majority of the observed fractures are cemented (i.e. veins), though a few non-mineralized fractures also occur.

Descriptive properties derived from macroscopic observations (i.e. facies, depositional environment, occurrence of differently oriented fractures) and analyses (i.e. TOC) of the two studied 
well cores were classed and converted into numerical codes (Table 1). A continuous sampling along the two logs was done and Excel spreadsheets were completed with the evolution of the different properties with depth (Table S3a and Table S3b of the Supplemetary Material). A total of 232 and 576 points were sampled on the logs for well cores $12-36$ and 16-17, respectively. These spreadsheets served as input in the EasyTrace ${ }^{\mathrm{TM}}$ software in order to convert the original descriptive information into a quantitative dataset to achieve frequency distribution analysis of the different properties (see details on this approach in Gasparrini et al., 2017). Using EasyTrace ${ }^{\mathrm{TM}}$ multivariate statistical analysis with the compiled spreadsheets enabled us to highlight the link between the type of depositional facies (with their TOC)and the occurrence and orientation of the fractures, as well as the fracture distribution within the different stratigraphic sequences of the studied formations.

Fifty samples, mostly containing mineralized fractures were collected from the two studied wells ( 23 from $16-17$ and 27 from 12-36). The samples were used to make thin polished and thick double-polished sections for petrographic, geochemical and fluid inclusion studies. The vein hostrock from these samples was milled and analyzed with Rock-Eval 6 pyrolysis. Here follow the details on the different methodologies and apparatus used.

Thirty-seven polished thin sections (30-35 $\mu \mathrm{m}$ thick) were prepared for conventional and cathodoluminescence $(\mathrm{CL})$ microscopy, as well as for staining. Thin section petrography performed on a Nikon ECLIPSE LV100 POL equipped with a mercury vapor lamp (100 W) allowing UV-light observations. Calcite crystal habitus and crystal spatial arrangement (texture) in the fractures were described using the terminology suggested by Bons et al. (2012) and Woodcock et al. (2007). For samples affected by dolomitization the dolomite texture classification from Sibley and Gregg (1987) was used. The cold-cathode CL device used is a 8200 Mk5-2 (CITL) which was employed under vacuum ( $<0.1 \mathrm{mBar}$ ) and with $250 \mu \mathrm{A}$ and $10 \mathrm{kV}$ operating conditions. A portion of all thin sections was stained with a solution composed of diluted $\mathrm{HCl}(10 \%)$ with Alizarin red $-\mathrm{S}$ and potassium 
ferricyanide to distinguish calcite from dolomite and qualitatively estimate their Fe content (Dickson, 1966).

Seven double-polished thick sections (100-120 $\mu \mathrm{m}$ thick) were prepared for Fluid Inclusion (FI) petrography and microthermometry measurements. Different $\mathrm{Fl}$ assemblages were distinguished based on their location within the crystals, e.g. crystal cores, growth zones, along trails, isolated. For bi-phase Fls, the volumetric proportion of the liquid phase relative to the total volume of the Fl, referred as degree of fill (F), was calculated at room temperature from 2D screen images by measuring areas. Microthermometry was carried out with a Linkam MDS 600 stage mounted on a Nikon LV100 Eclipse, with a 100 W Mercury vapor lamp which allowed UV-light observations. The stage was calibrated with synthetic Fls in the temperature range -56.6 to $+135^{\circ} \mathrm{C}$. The Linksys 32 software enabled all the operations for Fl microthermometry. The measurement accuracy was of 1 and $0.2^{\circ} \mathrm{C}$ for heating and cooling runs, respectively. For aqueous fluids, heating runs were accomplished before cooling runs. Salinities were calculated from final melting of ice (Tmi) in the binary $\mathrm{H}_{2} \mathrm{O}-\mathrm{NaCl}$ system (Bodnar, 1993). Oil density was qualitatively estimated from fluorescence color of hydrocarbon Fls based on the chart from McLimans (1987).

Carbonate (calcite) powders from the targeted veins were extracted from polished rock slabs by means of a dental drill to be analyzed for oxygen (O), carbon (C) and strontium (Sr) isotopes.

Forty-one calcite powders were analyzed for $\mathrm{O}$ and $\mathrm{C}$ isotopes. The samples were reacted with $100 \%$ phosphoric acid at $70^{\circ} \mathrm{C}$ up to 7 hours. A Gasbench II connected to a Thermo Finnigan Five Plus mass spectrometer was used. All values for carbonate phases are reported in per mil relative to V-PDB by assigning a $\delta^{18} \mathrm{O}$ value of $-2.20 \%$ and a $\delta^{13} \mathrm{C}$ value of $+1.95 \%$ to the NBS19 standard. Reproducibility was checked by replicate analysis and is better than $\pm 0.07 \%$ for $\delta^{18} \mathrm{O}$ and $\pm 0.06 \%$ for $\delta^{13} \mathrm{C}(1$ std. dev).

Eleven calcite powders were also analyzed for Sr isotopes. Carbonate samples were leached in ammonium acetate to remove groundwater salts and displace contaminant $\mathrm{Sr}$ on exchangeable 
sites (e.g. Bailey et al., 2000). The remaining material was rinsed twice in deionized water, and then

dissolved in dilute $\mathrm{HCl}$. After ion exchange chemistry, samples were loaded onto purified Re filaments in a Ta emitter solution (Birck, 1986). Isotopic analyses were made on a VG-Sector-54 thermal ionization mass spectrometer using a three cycle dynamic multicollector routine and an exponential mass fractionation correction relative to ${ }^{86} \mathrm{Sr} /{ }^{88} \mathrm{Sr}=0.1194$ (e.g. Hans et al., 2013). Repeated measurements of reference material NBS987 at similar run conditions during the period over which the analyses were made yielded a value indicating that the measurement repeatability is commensurate with the within-run uncertainty.

The Rock-Eval 6 pyrolysis apparatus was used to calculate, among other parameters, the TOC, the Hydrogen Index ( $\mathrm{HI}$ ) and the Mineral Carbon (MinC) of 46 fracture host-rock samples. The Shale Play Method ${ }^{\circledR}$ developed at IFP Energies nouvelles (Pillot et al., 2014; Romero-Sarmiento et al. 2016a, 2016b) was used on bulk-rock samples, allowing for a better estimate of the free or absorbed hydrocarbons in the rocks. $50-70 \mathrm{mg}$ of powdered sample is heated in an open pyrolysis system under non-isothermal condition (from 300 to $650^{\circ} \mathrm{C}$ ). During this pyrolysis, the amount of hydrocarbons released is measured by a flame ionization detector (FID) and $\mathrm{CO}$ and $\mathrm{CO}_{2}$ release are monitored with an infrared (IR) detector. The residual sample is then put in an oxidation oven where it is heated (from 300 to $800^{\circ} \mathrm{C}$ ) under artificial air $\left(\mathrm{N}_{2} / \mathrm{O}_{2}: 80 / 20\right)$. During combustion, the amount of $\mathrm{CO}$ and $\mathrm{CO}_{2}$ released are monitored with an IR detector. solvent extraction. The powdered samples were placed in a solution of dichloromethane and methanol $(1 / 1)$ in an ultrasonic bath at $40^{\circ} \mathrm{C}$ for 30 minutes. The samples were then filtered and placed in a drying oven for one day. Finally, the samples of extracted organic matter were analyzed again by using the Shale Play Method ${ }^{\circledR}$ of the Rock-Eval 6 apparatus described above. 
271

272

273

274

275

276

constant heat flow of $47 \mathrm{~mW} / \mathrm{m}^{2}$, and then $57 \mathrm{~mW} / \mathrm{m}^{2}$ was imposed at the base of the sedimentary pile, based on a lithospheric model, and thermal calibration was achieved by making use of vitrinite reflectance data to test the two heating scenarios (Ness 2001; Ducros et al., 2017). This model takes into account the amplitude of the Tertiary uplift, with an estimated thickness of eroded sediments that ranges from $4000 \mathrm{~m}$ close to the Rocky Mountains (Roure et al., 2010) to less than $400 \mathrm{~m}$ near the Precambrian shield in Saskatchewan (Ness, 2001; Higley et al., 2005; Roure et al., 2010).

\section{RESULTS}

The main results from well core logging, facies analysis and stratigraphy are reported in figure 3 together with the location of the studied samples and their TOC and MinC from Rock-Eval pyrolysis. Table S1a and Table S1b (see Supplementary Material) summarize details on the samples collected from wells $16-17$ and $12-36$, respectively, together with the sample depth, sequence of provenance, fracture orientation and kinematic aperture, petrography of the calcite sealing cements and their O-C isotope composition. Table S2a and Table S2b (see Supplementary Material) report the results of Rock-Eval pyrolysis for the rock samples hosting the fractures (on bulk-rock and extracted organic matter, respectively) for the two well cores investigated. Finally, Table S3a and Table S3b (see Supplementary Material) report the data-sheets with the evolution of the different properties with depth, used for frequency distribution analysis with Easytrace ${ }^{\mathrm{TM}}$ software.

\subsection{Sedimentology}

In this contribution, we primarily refer to detailed descriptions of the sedimentary facies previously published (Crombez et al., 2016; Playter et al., 2018). The two studied wells are located in the distal area of the WCSB where a narrow range of grain size and a dolomitic-feldspathic composition is expected to dominate the Montney lithologies, as due to arid climate conditions 
during deposition (e.g. Euzen et al., in press; Zonneveld and Moslow, 2018). They contain relatively hard grains (e.g. quartz, feldspars, carbonates), moderate amounts of organic matter and, locally, a relatively high content of clay minerals (e.g. Euzen et al., 2018; Vaisblat, 2020).

Petrographic observations on thin sections indicate that the investigated samples have grain size from very fine sandstone to fine siltstone, locally with clays. In particular, the Montney samples are often characterized by consistent grain size with silt-sized particles of $10-25 \mu \mathrm{m}$ being dominant, locally with very fine sands $(<80 \mu \mathrm{m})$, whereas the more clay-rich intervals could not be further characterized due to the limited resolution of the conventional optical microscopy used. On the other side, QEMSCAN images available for part of well 12-36 (British Columbia Oil and Gas Commission public database) suggest that the grain size mostly ranges between 15 and $30 \mu \mathrm{m}$. Both these datasets allow to consider the studied lithologies as mudrocks, according to the definition of Lazar et al. (2015) which includes silt-sized particles (fine $\operatorname{mud}<8 \mu \mathrm{m}$, medium mud=8-32 $\mu \mathrm{m}$ and "coarse mud" $=32-64 \mu \mathrm{m})$.In this contribution, we primarily refer to detailed descriptions of the sedimentary facies previously published (Crombez et al., 2016; Playter et al., 2018). Ten facies associations were identified (Fig. 3 and 4) by conducting a higher resolution lithology and facies analysis combined with the microfacies analysis from thin section petrography : 1 . Lag; 2 . Massive fine-grained sandstones; 3 . Massive very fine-grained sandstones to siltstones; 4 . Sand-dominated alternation of very fine-grained sandstones to siltstones; 5 . Silt-dominated alternation of very finegrained sandstones to siltstones; 6 . Massive siltstones; 7. Organic-rich massive siltstones; 8 . Bioclastic siltstones; 9. Laminated siltstones with mm-thick sand laminae (low density turbidite); 10. Laminated siltstones.

The ten facies associations identified were then grouped into four main depositional environments: (1) lag, (2) shoreface, (3) offshore transition, (4) offshore. Given the distal position of the wells in the basin, the very proximal depositional environments (e.g. foreshore or tidal) were not 
encountered. Lag deposits do not strictly represent a depositional environment since they are rather related to erosional and reworking processes influenced either by wave-, or storm-action.

\subsection{Rock-Eval pyrolysis}

The Montney and Doig Fms contain organic matter of type II and III (Crombez et al., 2016; Riediger, 1997; Romero-Sarmiento et al., 2016b). The mean TOC is in the range 0.5\% - 4wt\% and up to $8.2 \mathrm{wt} \%$ TOC in the Montney Fm, and may reach $11 \%$ in the Doig Fm within the Doig Phosphatic Member at the base (Riediger et al., 1990a; Ibrahimbas and Riediger, 2004; Crombez et al., 2016; Romero-Sarmiento et al., 2016b). in this study by stratigraphic sequence and by well . The complete dataset acquired in the present study by Rock-Eval analysis is reported in Table S2a and Table S2b (see Supplementary Material). the samples having TOC above $3.00 \%$. In particular, a mean TOC of $1.68 \%$ is recorded from the 26 samples of the $12-36$ well, whereas a mean of $1.91 \%$ is recorded from the 20 samples of the $16-17$ well; the highest value of $6.65 \%$ is recorded in the $16-17$ well at the TST of sequence 4 , corresponding to the Doig Phosphatic Member. occurred.

The pyrolysis results obtained from the 10 samples analyzed twice (i.e. on bulk-rock and on extracted organic matter) were compared. The procedure of organic matter extraction eliminated all the light hydrocarbons (free and adsorbed) and part of the heavy and very heavy hydrocarbons. The 
TOC values obtained on bulk-rock and extracted organic matter are similar (see Table S2a and Table

$343 \mathrm{~S} 2 \mathrm{~b}$ in Supplementary Material), suggesting that only the carbon from organic matter contributes to

344 the TOC computation. This ensures the reliability of the TOC values from the remaining 36 samples which were analyzed on the bulk rock only.

Crombez et al. (2016) previously published TOC and MinC values from continuously sampled cores and cuttings (155 samples) of the same wells. Measurements were done by means of the same Rock-Eval 6 apparatus, though by using the classic method (Lafargue et al., 1998; Pillot et al., 2014). TOC values measured by these previous authors were compared to those measured on close samples during this study for a quality check; the values from the two independently obtained datasets mostly overlap, the TOC difference being within the uncertainty range. This also confirms that the classic and the Shale Play Method ${ }^{\circledR}$ of the Rock-Eval 6 apparatus lead to equivalent TOC computation (as already underlined by Romero-Sarmiento et al., 2016a, 2016b).

Figure 5 reports the frequency distribution of the available TOC data (in wt. \%) by comparing the values measured in this study (on fracture host-rock samples only) with the full dataset by also including the values measured by Crombez et al. (2016). The figure illustrates that the two TOC datasets have an overlapping distribution, the only minor difference being that in our dataset samples with TOC of 1-2 wt. \% are more represented. This suggests that the TOC data at fractures here produced is representative of the whole TOC dataset available for the studied well cores.

\subsection{Host-rock diagenesis} revealed that several diagenetic events affected the studied formations after deposition. The study was focused on the carbonate diagenetic phases occurring as cements or replacements, therefore potentially affecting the rock mechanical properties. Here follow the details on the main diagenetic phases observed. 
A first calcite $(\mathrm{C} 1)$ may pervasively cement the most proximal (bioclastic) samples by filling

the intergranular pores between bioclasts. It is composed of non-ferroan calcite crystals $(10-60 \mu \mathrm{m})$ displaying a uniform and bright orange response under CL. It is rarely observed and is considered of minor extent in the studied wells.

A first dolomite (D1) may totally or partially replace the detrital carbonate grains. It consists of non-ferroan euhedral to sub-hedral crystals $(10-30 \mu \mathrm{m})$, building up a planar-E texture and displaying a uniform to zoned dull orange to dull red $\mathrm{CL}$ (Fig. 6A).

These first two phases (C1 and D1) are interpreted to have precipitated during eogenesis (i.e. early diagenesis) because of their non-ferroan nature. Furthermore, samples affected by C1 cementation lack major mechanical compaction features, suggesting that C1 precipitation occurred before significant burial.

Mechanical compaction is witnessed in many samples by micro-fracturing of bioclasts, as well as by the presence of grain to grain (locally interpenetrated) contacts .

A second dolomite (D2) mainly occurs as a cement since it forms overgrowths (5-10 $\mu \mathrm{m}$ thick) around detrital carbonate grains commonly replaced by D1 (Fig. 6B), although locally it also replaces the carbonate grains.. It is composed of ferroan dolomite crystals showing a uniform to zoned bright red CL (Fig. 6B).

A third dolomite (D3) may totally replace specific bioclastslike the calcispheres (Fig. 6C). It consists of ferroan anhedral crystals $(10-50 \mu \mathrm{m})$, which make up a non-planar texture, do not luminesce under CL (Fig. 6D) and acquire a deep blue color after staining.

The ferroan nature of these latter two dolomite phases (D2 and D3) points towards a precipitation during mesogenesis, in the burial environment, where reduced $\mathrm{Fe}^{2+}$ may commonly be available for uptake into the carbonate lattice upon crystallization. 
A second calcite (C2) phase mainly occurs as a cement within intergranular pores. It consists of non-ferroan granular to blocky crystals $(10-50 \mu \mathrm{m})$ with a uniform bright orange luminescence. It possibly precipitated after major mechanical compaction as suggested by the presence of compaction features (e.g. grain to grain interpenetrated contacts) in samples pervasively affected by C2 cementation. C2 may also occur as a replacement of previously precipitated carbonate phases (Fig. 6E and F).

Pyrite occurs in all samples both as small framboids $(<5-10 \mu \mathrm{m})$ or in large euhedral crystals $(10-50 \mu \mathrm{m})$. It replaces mainly the bioclasts and the early diagenetic calcites but also the third (ferroan) dolomite occurring within calcispheres.

Some of the above diagenetic phases may preferentially occur in facies from one or more depositional environments. For instance, the first dolomite (D1; eogenetic replacement) is observed only in samples from the 16-17 well, mainly from the shoreface environment and secondarily from the offshore transition environment. Furthermore, the third dolomite (D3; burial replacement) always occurs in facies containing calcispheres which are dominantly found in samples from the offshore transition and the offshore environments. The other diagenetic phases described above do not seem to be facies specific and are observed in similar proportions in all of the identified depositional environments.

PDiagenesis studies on the Montney Fm were conducted by previous authors (Vaisblat et al.,2017b, Vaisblat 2020). Vaisblat et al. (2017b) investigated 83 samples coming from two wells located in British Columbia for petrography (SEM), mineralogy (XRD) and geochemistry (QEMSCAN). In particular, 68 samples out of the 83 come from well 16-17, also investigated in the present study. Our observations (though based on optical petrography and CL only) were therefore compared with those of Vaisblat et al. (2017b); the main differences are illustrated in figure 7. This comparison reveals that in the present study authigenic clay minerals, quartz cement and feldspar dissolution/precipitation were not observed, due to the limited resolution of the conventional optical 
microscopy. On the other hand, some carbonate phases were here documented for the first time (Fig. 6); these are the non-ferroan first calcite (C1) and first dolomite (D1) phases, precipitated during eogenesis and the ferroan third dolomite (D3), precipitated during burial within calcispheres.

Interestingly, no diagenetic sulfates were detected in the Montney-Doig lithologies of the studied well cores, in contrast with the observations made in well cores located further to the south (Liseroudi et al., 2020), i.e. within the inherited structure from the Paleozoic PRAcollapse (Fig. 1A).

\subsection{Fracture orientation and abundance}

All the fractures (both mineralized and non-mineralized) observed along the 16-17 and 12-36 vertical well cores were reported on the sedimentological logs. Macroscopically, the fractures were classified according to their orientation (Fig. 8): horizontal (bedding-parallel) or vertical (vertical s.s. or at high angle to bedding). The persistence of the vertical to high angle fractures mostly ranges from 3 to $10 \mathrm{~cm}$ and only rarely exceeds $20 \mathrm{~cm}$; the persistence of the horizontal fractures could not be estimated since it exceeded the core width.

For the properties recorded on the sedimentological logs (i.e. facies associations, depositional environments, stratigraphic sequences, occurrence and orientation of the fractures) and for those measured in the laboratory (i.e. TOC) different classes were established and expressed by means of numerical codes (Table 1).

The complete spreadsheets used for statistical treatment with EasyTrace ${ }^{\mathrm{TM}}$ software are reported in Table S3a and Table S3b (see Supplementary Material) for wells 16-17 and 12-36, respectively. The treatment of these data highlighted different possible correlations between the abundance and orientation of the fractures and the host-rock features as well as their distribution within the four stratigraphic sequences (Fig. 9). 
The 10 facies associations (property here referred to as FACIES) previously identified (Fig. 3 and 4) were grouped into four broad depositional environments (property here referred as ENVIRONMENT) as follows: the lag (code 1), the shoreface (code 2) which groups the facies associations 2 and 3, the offshore transition (code 3) which groups the facies associations 4 and 5 and the offshore (code 4) which groups the facies associations 6, 7, 8, 9 and 10 (see Table 1). formations were classed from 1 to 4 (Table 1 ) as follows: sequence 1 (code 1), sequence 2 (code 2), sequence 3 (code 3 ), sequence 4 (code 4 ). (code 2), 2-3\% (code 3), 3-4\% (code 4), 4-5\% (code 5), 5-11\% (code 6). (code 3).

Figure 9 illustrates the results of the statistical treatment with EasyTrace ${ }^{\mathrm{TM}}$ software for the two wells. The red lines represent the distribution of the whole sampled points where fractures occur (i.e. only the points with codes 2 and 3 of the property FRACTURE). Figure 9A and 9B show respectively the distribution of sampled points characterized by the presence of horizontal and vertical to high angle fractures; the black bars indicate in which SEQUENCE, ENVIRONMENT and TOC classes fall the sampled points corresponding to fracture occurrence. The values reported as "777" correspond to undefined, though not null, values that were indeed attributed to cells of the log spreadsheets when information on a given property was not available. This is because at the same well depth information may not be available for all properties (see Table S3a and Table S3b of the 
Figure 9A indicates that the horizontal fractures (code 2 of the property FRACTURE)are

similarly abundant in 3 of the 4 stratigraphic sequences (property SEQUENCE) and are rare only in sequence 3. They occur in nearly all facies associations (property FACIES). In particular, the massive siltstones (code 6 ) host $28 \%$ of the fractures, whereas the bioclastic siltstones (code 8 ) and the siltdominated alternation (code 5) host respectively 7 and $5 \%$ of the fractures. Globally, the depositional environment (property ENVIRONMENT) named offshore (code 4) hosts the majority of horizontal fractures. No relationship between the abundance of the horizontal fractures and the host-rock TOC could be highlighted.

Figure 9B indicates that the vertical to high angle fractures (code 3 of the property FRACTURE)are similarly abundant in 3 of the 4 stratigraphic sequences (property SEQUENCE) and are fairly less represented in sequence 3. They occur in almost all facies associations (property FACIES). In particular, the sand-dominated alternation (code 4) hosts $29 \%$ of the fractures, whereas the massive fine-grained sandstones (code 2) and the bioclastic siltstones (code 8) host respectively 4 and $3 \%$ of the fractures. Globally, the depositional environment (property ENVIRONMENT) named offshore transition (code 3), characterized by sand-rich facies, hosts the majority of the vertical fractures. These fractures seem to occur mainly in rocks with low TOC, i.e. between 1 and $2 \%$ (code 2 of the property TOC).

\subsection{Vein petrography}

All the investigated mineralized fractures (i.e. horizontal and vertical to high angle veins) are fully sealed by calcite cements, leaving no fracture porosity left. Despite the monotonous mineralogy, the calcite cements display various crystalline habitus (e.g. fibrous, blocky and elongated blocky) and spatial arrangement (i.e. texture) within the veins. Details on the petrographic features of all the studied samples (including the fractures and the sealing calcite cements) can be found in Table S1a 
and Table S1b (see Supplementary Material). The nomenclature used is after Woodcock et al. (2007) and Bons et al. (2012). elongated blocky to blocky. In all these cases, the crystals have syntaxial (both symmetrical or asymmetrical) or antitaxial arrangements suggesting that calcite precipitation occurred during fracture opening (syn-kinematic calcite). Features suggesting a crack-seal mechanism for vein opening are common; we could observe several bands of calcite oriented parallel to the vein walls which represent repeated opening events progressively sealed by calcite (Ramsay, 1980; Laubach, 2003). The calcite cement may therefore be considered as syn-kinematic, since crack-seal textures form as cement precipitates during progressive vein widening. Our observations also suggest that in most cases, the horizontal veins opened in mode I, even though we could observe in very few cases evidence for mixed mode I-mode II opening (Fig. 10C and D).

All the vertical to high angle fractures are sealed by blocky to elongated blocky calcite crystals (Fig. 10). In the first case a drusy texture may be observed with the crystal size increasing towards the vein center, whereas in the second case the crystals have a syntaxial arrangement (both symmetrical and asymmetrical). Features corresponding to crack-seal mechanism of vein opening have been only locally observed. More commonly the vein terminations display tortuous forms, with axial planes and B). 
Interestingly, all calcite cements sealing the fractures, irrespective of the well core of

belonging, fracture orientation and crystal habitus/texture, display, when observed under UV-light, the same response given by uniform and very dull green fluorescence. Similarly, the calcite cements cannot be distinguished when observed under $\mathrm{CL}$ as they all show a relatively uniform dull to very dull orange color.

Cross-cutting and abutting relationships between horizontal and vertical to high angle veins were only locally observed, therefore the vein relative chronology is not easily assessed from petrography only. However, where cross-cutting relationships are observed, they indicate that some of the vertical veins post-date the horizontal ones since the calcite crystals of the vertical vein replace the calcite crystals of the horizontal one at the vein intersection (Fig. 10G and H).

\subsection{O-C-Sr isotope geochemistry}

The results of the O-C stable isotope analyses performed on the vein calcite cements are reported in figure 11 . The $\delta^{18} \mathrm{O}$ ranges between -8.27 to $-11.18 \%$ (mean $-10.45 \%$ ), whereas $\delta^{13} \mathrm{C}$ ranges from 1.34 to $-4.38 \%$ (mean $-1.09 \%$ ). When separating the calcite samples per well of belonging it comes that calcite from well $16-17$ has $\delta^{18}$ O ranging from -8.27 to $-10.7 \%$ (mean 9.69\%o) and $\delta^{13} \mathrm{C}$ ranging from 1.04 to $-4.3 \%$ o (mean $-1.86 \%$ ), whereas calcite from well $12-36$ has $\delta^{18} \mathrm{O}$ varying from -10.72 to $-11.18 \%$ (mean $-10.72 \%$ ) and $\delta^{13} \mathrm{C}$ varying from 1.34 to -3.43 (mean $0.82 \% \circ)$

Analyzed calcites display a very negative $\delta^{18} \mathrm{O}$ compared to calcite precipitated in equilibrium with Early Triassic seawater (Fig. 11; Veizer et al., 1999). Based on the well-established dependency of $O$ isotope fractionation on temperature (O'Neil, 1969), such negative $\delta^{18}$ O values suggest calcite precipitation at burial temperatures. 
$534(\sim 4 \%)$ and may be due to the contribution of different amounts of light ${ }^{12} \mathrm{C}$ from the host-rocks to

the calcite parent fluids. Indeed, in well 12-36, the most negative $\delta^{13} \mathrm{C}$ values are recorded by calcites hosted in sequence 3 (Fig. 11A), which is characterized by the highest mean TOC among the three sequences recorded in this well (Table 2). Similarly, in well 16-17, the most negative $\delta^{13} \mathrm{C}$ values are recorded in samples from sequence 4 (Fig. 11B), which records the highest TOC values of the whole dataset analyzed (Table 2).

Calcites from different well cores and differently oriented veins have overlapping $\mathrm{Sr}$ isotope composition (Table S1a and Table S1b of Supplementary Material). Indeed, 10 of the 11 calcites investigated display ${ }^{87} \mathrm{Sr} /{ }^{86} \mathrm{Sr}$ falling in the narrow range comprised between 0.7112 and 0.7124 , with only one calcite having lower values (0.7091). Compared with calcites precipitated in equilibrium with Early to Middle Triassic seawater, which have ${ }^{87} \mathrm{Sr} /{ }^{86} \mathrm{Sr}$ in the range 0.706940 to 0.708219 (Veizer et al., 1999), all of the fracture calcites investigated result to be enriched in the radiogentic ${ }^{87} \mathrm{Sr}$ isotope.

Overall, these results indicate that the investigated calcites show little variations in isotope compositions irrespective from crystal habitus and texture, vein orientation and well of belonging.

\subsection{Fluid inclusion (FI) study}

Of the 7 samples prepared for Fluid Inclusion (FI) study only 4 could be investigated for microthermometry. This is because the three other samples consist of fractures sealed by fibrous calcite crystals for which microthermometry measurements were unfeasible due to the small size of the Fls. Four different types of Fls (Type I, Type II, Type III, Type IV) were distinguished petrographically and may show shapes like negative crystals or controlled by crystallographic planes

(Fig. 12 and Table 3). The main results of Fls microthermometry are reported in Table 3 and Fig. 13. 
Type I consists of aqueous, bi-phase, liquid-rich Fls with degree of fill (F) between 0.89 and

558 0.95; they occur in crystal cores, along trails or isolated and do not show fluorescence under UV-light

559 (Fig. 12A and B). Homogenization occurs in the liquid state at temperatures (Th) between 78 and $118^{\circ} \mathrm{C}$ with mode value at $100^{\circ} \mathrm{C}$. During cooling after homogenization most Fls develop a gas bubble at temperatures between 88 and $62^{\circ} \mathrm{C}$. During further cooling they freeze at temperatures between 67 and $-70^{\circ} \mathrm{C}$. During reheating after freezing, on some Fls $(n=15)$ the occurrence of a first liquid (i.e. the apparent eutectic, which overestimates the real eutectic) was observed optically at temperatures between -21.9 and $-18.4^{\circ} \mathrm{C}$, suggesting that the aqueous fluid is dominated by $\mathrm{NaCl}$. Ice is possibly the last phase to melt (as deduced from the roundish shape and the whitish color of the crystals) with a stable behavior (gradual melting allowing cycling procedure). Final melting of ice (Tmi) occurs between -19.3 and $-16.0^{\circ} \mathrm{C}$. Fluid salinity, calculated on $15 \mathrm{Fls}$, varies between 19.4 and 21.9 eq. $\mathrm{NaCl}$ $w t \%$ (mode is 20). The salinity of Type I Fls is about six times higher than normal seawater, suggesting that the calcites precipitated from saline basinal brines. The Th measured represent FI minimum trapping temperatures. To estimate the real trapping temperatures an isochore was constructed using the mode values of $\mathrm{Th}\left(100^{\circ} \mathrm{C}\right)$ and salinity $(20 \mathrm{eq} . \mathrm{NaCl}$ wt\%) and combined with a thermobarometric gradient of $30^{\circ} \mathrm{C} / \mathrm{km}$. This gradient is consistent with the basin evolution during Mesozoic time, as deduced from the available TemisFlow ${ }^{\mathrm{TM}}$ model. A pressure correction of $10^{\circ} \mathrm{C}$ was evaluated for Type I Fls pointing to a possible trapping temperature of $110^{\circ} \mathrm{C}$.

Type II is made of oil, bi-phase, liquid-rich Fls with $\mathrm{F}$ between 0.8 and 0.92 ; they occur in crystal cores, along trails or isolated and show a green fluorescence under UV-light (Fig. 12C and D).

577 Homogenization in the liquid state occurs at temperatures (Th) falling within the 24 to $58^{\circ} \mathrm{C}$ range with mode value of $31^{\circ} \mathrm{C}$. During cooling after homogenization all Fls develop a gas bubble between 48 and $26^{\circ} \mathrm{C}$. During cooling runs no solid phases are observed to form. 
582

583

584

585

586

587

588

589

590

591

592

593

594

595

596

597

598

599

600

601

602

603

604

observed during heating and cooling runs and the Fls remain monophase. No microthermometry measurements could be performed.

Type IV comprises mono-phase, liquid Fls with $\mathrm{F}=1$; they occur in crystal cores, along growth zones, isolated or along trails. They consistently show shapes from negative crystal to crystallographic controlled. Some of them display weak yellow to green fluorescence whereas some others do not show any fluorescence under UV-light (Fig. 12E and F). During cooling from room temperature, the mono-phase liquid Fls develop a gas bubble at temperatures between -60 and $74^{\circ} \mathrm{C}$. The Fls persist in the bi-phase state down to $-150^{\circ} \mathrm{C}$ with no observable solid phase being formed. During reheating the bi-phase Fls homogenize in the liquid state. Homogenization temperatures (Th) are comprised between -76 and $-62^{\circ} \mathrm{C}$ with mode value at $-70^{\circ} \mathrm{C}$. The behavior of Type IV Fls suggests they may be carbonic Fls, belonging to the $\mathrm{CH}_{4}-\mathrm{CO}_{2}-\mathrm{N}_{2}$ fluid system. The behavior of these fluids depends on their density and on the relative proportions of the different components (Van den Kerkhof and Thiery, 2001; Conliffe et al., 2017). In particular, for a pure $\mathrm{CH}_{4}$ system, Th values of $-80^{\circ} \mathrm{C}$ are expected with Th becoming less negative with increasing proportions of $\mathrm{CO}_{2}$. Th values measured for Type IV FIs (Table 3 ) are in line with a system dominated by $\mathrm{CH}_{4}$ with some quantities of $\mathrm{CO}_{2}$, although the presence of other hydrocarbons, such as $\mathrm{C}_{2} \mathrm{H}_{6}$ or $\mathrm{C}_{3} \mathrm{H}_{8}$, cannot be excluded. Preliminary characterization of Type IV FIs with Raman spectroscopy also revealed the presence of $\mathrm{CH}_{4}$, though the high fluorescence of the host calcite mineral did not allow a more quantitative evaluation.

\section{DISCUSSION}

\subsection{Host-rock controls on fracture fracture occurrence}


A number of papers have addressed the multiple factors controlling the occurrence of fractures in siliciclastic tight reservoir rocks (Engelder and Peacock, 2001; Rijken and Cooke, 2001; Peacock and Mann, 2005; Wang and Gale, 2009; Gale et al. 2014; Wang et al., 2016; Ilgen et al., 2017; Hooker et al., 2020; Peng et al., 2020). Many factors, such as tectonic stress, lithology, reservoir thickness, abundance of organic matter, mineralogy and cementation have been recognized as potentially exerting a control on the brittleness of the rock (i.e. the easiness of a rock to be fractured and its ability to maintain a fracture). hosted in fine siliciclastic rocks such as the shales and the siltstones. Present day brittleness can be evaluated based on either lithology or elastic properties. In general, the higher the Young's modulus and the lower the Poisson's ratio, the more brittle the rock. For instance, rock mechanical tests indicate that under the same stress conditions, a shale will have higher brittleness and smaller tensile strength if it has lower Poisson's ratio and higher Young's modulus (Ding et al., 2012). fracture system development, both natural and stimulated. The content in relatively hard minerals such as quartz, feldspar and carbonates has been found to be positively correlated with the number of fractures and/or brittleness of the shale (Perez and Mafurt, 2013; Zeng et al., 2013; Hu et al. 2015; Labani and Rezaee 2015; Rybacki et al., 2015; Wang et al., 2017). Conversely, a high clay content makes the shale more ductile (Aoudia et al., 2010, Perez and Mafurt, 2013; Dong et al., 2017, 2018). The brittleness of a shale can therefore be predicted from the volumetric fraction of clay, quartz, feldspar and carbonate contents by treating the rock as a composite material and by calculating its elastic properties by the rule of mixture (Pei et al., 2016), though this approach does not take into account the effect due to the form of grains (Peng et al., 2020). The influence of TOC and organic maturity on brittleness of tight siliciclastic rocks is still debated. In the Nuititang Shale the TOC shows a positive correlation with the number of fractures (Zeng et al., 2013). In the Barnett Shale, Perez and 
Mafurt (2013) show that contrary to the commonly held understanding, the increased TOC does not

632 make the rock more ductile, whereas Yasin et al. (2017) report that the TOC content has a positive correlation with the amount of quartz, and that organic maturity has a positive correlation with brittleness. Dong et al. (2018) also conclude that in the Duvernay shale, increased organic maturity results in greater hardness for rocks of similar geochemical compositions. Conversely, other studies suggest that the effect of organic matter content and maturity on the mechanical properties of a shale is subordinate to the rock mineral composition (Aoudia et al., 2010; Labani and Rezaee, 2015). In contrast with the well documented literature on shales, the relationship between composition and mechanical properties in siltstones is not well established. Brittleness of the Montney siltstones has been calculated from well-log averages (sonic, density, XRF, XRD) calibrated to static and measured data on cores (Vaisblat et al. 2017a, 2019; Chatellier et al., 2018).

The results of the present study derived from the analysis of cored intervals of wells 12-36 and 16-17 which dominantly corresponds to the Montney Fm and to a minor extent to the Doig Fm (Fig. 3), allow considering the succession investigated as being mostly composed by siltstones. According to the frequency distribution analysis accomplished (Fig. 9), based on a rather continuous sampling of the different properties (i.e. SEQUENCE, FACIES, ENVIRONMENT, FRACTURE, TOC) along the logs of the two well cores it could be concluded that:

such as sand-dominated alternation and silt-dominated alternation), chiefly composed by coarse silt and fine sand, hosts the majority of the vertical to high angle fractures. These rocks display low to moderate TOC (i.e. between 1 and 2\%).

massive siltstones, organic-rich siltstones, bioclastic siltstones, laminated siltstones), chiefly composed by fine silt (locally with clay), hosts the majority of horizontal fractures. No relationship between the abundance of the horizontal fractures and the host-rock TOC has been identified. 
On the other hand, the petrographic analysis accomplished under $\mathrm{CL}$, based on local observations (i.e. where thin sections were made; see list in Table S1a and Table S1B of the Supplementary Material) from the two investigated wells, suggests that the abundance of diagenetic carbonates (early or late diagenetic; Fig. 6 and 7) does not seem to be a main factor controlling the fracture occurrence, since most of the fracture host-rocks observed in thin section do not contain abundant diagenetic carbonates. An exceptions is represented by the offshore samples which seem to develop vertical fractures where abundant burial dolomite (D3) occurs.

and 12-36 (Fig. 3) is that the vertical facies changes of the studied lithologies (stacking pattern) seem to also influence the horizontal fracture occurrence: the higher the vertical facies heterogeneity, the more numerous the horizontal fractures.

According to these general results issued from the two studied wells it could thus be concluded that fracture occurrence in the Montney siltstones seems to be chiefly controlled by hostrock facies and vertical facies changes (stacking pattern) and to a minor extent by the abundance of diagenetic dolomite. Conversely, host-rock TOC seems not to be correlated with the fracture abundance.

In order to further characterize the factors controlling fracture occurrence in the studied lithologies, these general results issued from the study of the two wells were integrated with available data from well 12-36 on bulk brittleness (computed from XRD and XRF continuous logs and calibrated with core measurements; Chatellier et al., 2018) and mineralogy (British Columbia Oil and Gas Commission public database). Mineralogy is however only available for two of the three investigated cores (i.e. core 1 and core 3; Fig. 14). In spite of the unfortunate lack of mineralogy analysis for core 2 that shows the highest bulk brittleness, the comparison between mineralogy and bulk brittleness of cores 1 and 3 (Fig. 14) suggests that clays/mica content is negatively correlated with brittleness and stiffness. This comparison further shows (Fig. 14) that the calcite/dolomite and 
$\mathrm{K}$-feldspar/plagioclase contents of core 1 is higher than in core 3 , suggesting that these minerals may also control the bulk brittleness. Following Pei et al. (2014), it could be concluded that similarly to shales, the content in relatively hard minerals like feldspars and carbonates may enhance the brittleness of siltstones.

By combining the data on bulk brittleness for well 12-36 (Chatellier et al., 2018) with the occurrence/orientation of fractures (this study) it appears that the relationship between bulk brittleness and fracture occurrence is not straightforward (Fig. 14), so that fracture occurrence cannot be simply predicted from bulk brittleness derived from compositional logs only. Indeed, bedding-parallel horizontal fractures are observed in all of the three cores of well 12-36 despite the strong difference in bulk brittleness. This rather argues in favor of a control being also exerted by mechanical layering. Indeed, in contrast to core 1 which displays more homogeneous sedimentary facies and bulk brittleness, cores 2 and 3 include a number of depositional environments and facies and exhibit high frequency vertical changes in brittleness (Fig. 14). This results in horizontal fractures being less abundant in core 1 than in cores 2 and 3 . and conclusively suggests that the occurrence of horizontal fractures is mainly related to 1 ) the occurrence of internal facies laminations and 2) the number of interfaces between layers of different brittleness (i.e. sedimentary facies transitions). Therefore, the Montney siltstones like shales seem to exhibit a rather high strength anisotropy (weakness parallel to bedding), though they are stiffer and more brittle than common shales.

Concerning the vertical fractures of well 12-36 (Fig. 14), they mostly occur in core 3 which is composed by facies with the lowest bulk brittleness (likely due to the presence of high clays/mica contents; Fig. 14). This is again hard to explain from the bulk brittleness log only. The results of the present study suggested however that the facies coarseness and/or the presence of D3 ferroan dolomite had a potential role in concentrating these fractures. 
well 12-36 only (Chatellier et al., 2018, and British Columbia Oil and Gas Commission public database)

show that the Montney Fm siltstones have a peculiar mechanical behavior. Indeed, the fracture

occurrence seems not to be controlled by the host-rock TOC (Fig. 5 and Fig. 9). Furthermore, the lack

of direct correlation between the occurrence of fractures and bulk brittleness (calculated according

to Chatellier et al., 2018; Fig. 14) suggests that bulk brittleness cannot be used alone as a reliable

\subsection{Fracture timing and foreland evolution}

Timing of fracture opening is difficult to constrain, and without this information, ascribing them to a given specific mechanism, is problematic. In the absence of absolute radiometric dating of calcite vein cements (Beaudoin et al, 2018; Hansman et al., 2018; Mangenot et al., 2018; Parrish et al., 2018), relative constraints on fracture timing may come from field/core evidence of abutting/crosscutting relationships and petrographic evidence, combined with isotope geochemistry and thermometry evidence (Gabellone et al., 2013; Quesnel et al., 2016; Hooker et al., 2017b, 2019). In particular, the chemical and thermal signatures of the syn-kinematic vein cements reflect fluid conditions during fracturing, and hence may help constraining the timing of fracture opening if combined with thermal basin modeling accounting for the regional tectonic evolution (e.g. Roure et al., 2010; Gasparrini et al., 2014).

In this study, both vertical and horizontal mineralized fractures were investigated from wells 16-17 and 12-36 of the Montney-Doig Fms (Fig. 8 and 10). The strike for the vertical fractures is unknown, which hampers the definition of fracture sets based on their orientation. Therefore, the 
different mechanisms, chiefly based on petrography and Fl evidence. Having said this, three generations of veins were identified in the studied wells cores: the first and third oriented vertical to high angle and the second oriented horizontal. Syn-kinematic features like fibrous to elongated blocky calcite crystal habitus arranged in syntaxial to antitaxial textures and/or crack-seal mechanism evidences are common in the three vein generations (see figure 10 and Table S1a and Table S1b in the Supplementary Material), allowing to discuss the timing of vein opening from assessing calcite precipitation time.

The three generations of veins are hereafter integrated to the thermal/burial history of the Montney-Doig Fms and interpreted within the geodynamic evolution of the WCSB. (Fig. 15). With such aims, the temperature/depth evolution with time of the Montney-Doig Fms, modeled by the TemisFlow $^{\top \mathrm{M}}$ software, was used. A 1D thermal curve was extracted for the studied location from the available 3D model, by assuming a thickness of $3300 \mathrm{~m}$ of eroded sediments during the Tertiary uplift, according to previous structural restorations (Faure et al., 2004; Hardebol et al., 2009; Roure et al., 2010). The curve highlights four main stages in the geological evolution of the WCSB since the Triassic (Fig. 15): 1) a first stage governed by a retro-foreland regime in the Triassic; 2) a transition toward the Jurassic collisional foreland regime; 3) two phases of fast subsidence in the Middle Cretaceous and Latest Cretaceous - Early Paleocene, respectively, separated by a subsidence plateau in the Late Cretaceous; 4) a phase of exhumation and associated sediment erosion or bypass starting from the Early Paleogene, in association with the Laramide Orogeny. The two Cretaceous phases of subsidence and the Early Paleogene exhumation are well time-correlated with the tectonic pulses identified by Pană and van der Pluijm (2015). Notably, the temperatures modeled for the maximum rock burial do not exceed $150^{\circ} \mathrm{C}$ (given uncertainties), in agreement with the observation that the calcite from all veins displays thin and rectilinear twins (Fig. 10), suggesting that twinning occurred at temperatures below $170-200^{\circ} \mathrm{C}$ (Ferrill et al., 2004; Lacombe, 2010). 
that the oil generation had already started. Triassic source rocks from the WCSB started to generate hydrocarbons during the Late Cretaceous (88,5 Ma) based on Ducros et al. (2017), and even earlier based on Ness (2001). Accordingly, the age of the first vein generation is bracketed between $100 \mathrm{Ma}$ and $70 \mathrm{Ma}$, i.e. atimespan post-dating the beginning of oil generation and consistent with a $110^{\circ} \mathrm{C}$ burial temperature for the studied succession (Fig. 15). Thesevertical veins therefore possibly opened during the Late Cretaceous when vertical movements of the foreland were still limited and fast sedimentation of the Colorado Group had occurred (Pană and Van der Pluijm, 2015; Ducros et al., 2017, Rohais et al., 2018). Since the strike of these vertical veins is unknown, it is not possible to determine under which stress regime they developed. They could have formed either under a burial/flexure related vertical maximum principal stress $\sigma 1$ or under a horizontal maximum principal stress $\sigma 1$ oriented NE-SW that was likely prevailing during the Cretaceous in the Rocky Mountains (Vandeginste et al., 2012) if tectonic stress magnitude had already overcome the burial-related stress magnitude in the basin at that time (e.g. layer-parallel shortening, Tavani et al., 2015).

The horizontal, layer-parallel, veins (second generation) are cemented by calcite which hosts mono-phase liquid $\mathrm{CH}_{4} \pm \mathrm{CO}_{2}$ inclusions, together with oil inclusions, indicating that they formed after the onset of gas generation. Though the trapping conditions for these hydrocarbon inclusions could not be estimated, the presence of $\mathrm{CH}_{4}$ strongly suggests that the calcite cements precipitated at temperatures higher than $110^{\circ} \mathrm{C}$ (i.e. higher than the temperature inferred for the vertical veins of the first generation). Triassic source rocks from WCSB reached the maximum transformation rate just before maximum burial ( 58-57 Ma) which also corresponds to a maximum overpressure in these rocks, due to peak hydrocarbon generation and secondary cracking of oil into gas (Ducros et al., 2017). Therefore, the horizontal veins are interpreted to have formed during Late Cretaceous to Early Paleogene, just before the host lithologies reached the thermal/burial maximum (Fig. 15). Despite the multiple sources of uncertainties, the age for thermal/burial maximum ( $58-57$ $\mathrm{Ma}$ ) is rather close to the age of the last tectonic pulse ( 54-52 Ma) identified by Pană and van der Pluijm (2015). The formation of such horizontal, layer-parallel veins at nearly the maximum burial 
depth was likely associated with pore-fluid pressures exceeding the vertical overburden load (e.g. Price, 1975; Henderson et al., 1990). The mechanisms for opening horizontal fractures has been recently summarized by Hooker et al. (2019). In case of prevailing strike-slip faulting stress regime, the horizontal fracture opening would have required a poroelastic effect in response to fluid pressure increase in order to counteract the overburden and the lateral stress in proportion (Engelder and Fischer, 1994), flipping the vertical stress to be the least compressive stress by the time the tensile failure criterion is reached. However, the most likely explanation is that the bedding-parallel veins were related to catagenesis and formed from fluid overpressure within a thrust-faulting regime (in which the overburden is the least compressive stress), in line with the Eocene pulse of regional contraction (Pană and van der Pluijm, 2015) and the compressional or transpressional stress regime reconstructed by Vandeginste et al. (2012) in the Rocky Mountains to the South East. The overpressure increase, here likely induced by $\mathrm{CH}_{4}$ generation, is in agreement with earlier works emphasizing the role of hydrocarbon generation as potential drivers of fracture growth in organicrich mudrocks (Spencer, 1987; Ozkaya, 1988; Vernik, 1994; Jochum et al., 1995; Marquez and Montjoy, 1996; Zanella et al., 2014; Meng et al., 2017). Although the horizontal fractures are interpreted to be chiefly governed by gas generation, they are not more abundant in high TOC levels (Fig. 9). This apparent paradox may be explained by the entire succession being overpressured throughout together with the high frequency vertical facies changes of the studied rocks (already underlined in section 5.1). Indeed, these rocks consist of $\mathrm{dm}$ to $\mathrm{m}$ scale alternations of OM-rich and more arkosic/carbonatic siltstones; it seems likely that peak gas generation provided distributed fluid overpressures that concentrated fracturing in the more brittle beds located above or below the OMrich ones.

Finally, the third generation of vertical veins shows petrographic evidence for post-dating the bedding-parallel ones of second generation (Fig. 10G and H) and also contains monophase liquid $\mathrm{CH}_{4} \pm \mathrm{CO}_{2}$ inclusions. We propose that these vertical veins opened during basin uplift (Middle-Late Paleogene) that occurred after peak burial. Vein opening is here interpreted as resulting from the 
progressive decrease of the far-field horizontal stress magnitude and the transition from Laramide compression to regional transtensional faulting regime (Middle Paleogene). This new tectonic stress likely combined to residual fluid overpressure to drive the opening of the vertical fractures at depth. Indeed, the proposed fracture timing is in line with the study of Chatellier et al. (2018) who identified overpressure associated with tectonic uplift by comparing the reservoir pressures against normal hydrostatic pressure trends and also with the model of Ducros et al. (2017) indicating that a fluid overpressure regime persisted after thermal/burial maximum in areas where HC occurred.

In conclusion, the opening of the horizontal veins related to gas generation certainly required fluid overpressure to overcome the weight of the overburden. The occurrence of relatively abundant vertical veins at depth may indicate that their formation was also probably assisted by elevated fluid pressures. In this study however, the quantification of fluid pressure remained out of reach. Only the fine investigation of immiscible co-genetic fluid inclusions (e.g. Roure et al., 2010) or the joint application of thermometric techniques (e.g. Mangenot et al., 2017; Honlet et al., 2018) may potentially give access to fluid pressure conditions during calcite crystal growth and confirm the proposed hypotheses.

\subsection{Calcite parent fluids and openness of the system}

Paleo-water (or paleo-fluid) circulation in sedimentary basins plays a key role in governing burial diagenetic processes (Bjørlykke, 1994; Kyser et al., 2005; Roure et al., 2005). Previous studies have stressed the importance of establishing the origin of burial diagenetic fluids in siliciclastic successions (Morad et al., 2002; Bjørlykke and Jahren 2012; Deschamps et al., 2012). Indeed, aiming to predict the spatial and temporal distribution of diagenetic alterations at basin scale and the present day heterogeneities in the reservoirs, it is of prime importance to define whether reactions were accomplished by fluid advection (active flow) or diffusion (no flow), or in other words whether the fluids were locally sourced (closed system) or derived from external sources (open system). In 
this respect, the openness of fluid systems driving diagenetic reactions (including carbonate cementations) may be assessed by investigating the occurrence of mineral assemblages and their isotope and elemental geochemistry (Day-Stirrat et al., 2010; Fantle et al., 2010; Khalifa and Gasparrini, 2014; Swart, 2015). Organic-rich mudrocks represent a peculiar case of siliciclastic rocks, since together with the paleo-waters, they may host locally sourced hydrocarbon liquids. Here, the investigation of both diagenetic minerals and organic components may help to characterize the openness of the paleo-water and petroleum systems.

The Montney-Doig Fms have been long investigated at the scale of the WCSB to determine the origin of their hydrocarbons to finally discriminate if they mostly consist in tight reservoirs (where hydrocarbons migrated from an external source) or if they locally also behaved as sourcerocks (where hydrocarbons are internally sourced). It is commonly accepted that the Doig Fm contains a prolific source rock interval (the Doig Phosphate Zone) and produced liquid hydrocarbons (Creaney and Allan, 1990; Riediger et al., 1990; Allan and Creaney, 1991; Ness, 2001, Ejezie, 2007; Ducros et al., 2017). Conversely, despite the Montney Fm contains huge unconventional oil and gas resources (Neb, 2013), there is less consensus on the potential contribution of the Montney lithologies to the overall produced hydrocarbons. Indeed, the studies on organic components conducted so far do not find a common agreement and both hypotheses (tight reservoirs versus source rocks) are presently supported.

On one side, it is believed that the organic matter from the Montney rocks is composed almost entirely of solid bitumen or pyrobitumen (Chalmers and Bustin, 2012; Sanei et al., 2015; Wood et al., 2015, 2018, 2020; Ardakani et al., 2020). In particular, a modified Rock-Eval procedure and organic petrography were applied by Sanei et al. (2015) on Montney Fm samples from one well core located ca. $50 \mathrm{Km}$ South of Fort St. John, within the inherited structure from the PRA collapse. Based on the absence of primary deposited kerogen, these authors concluded that the majority of the TOC in the studied samples consists of solid bitumen (or pyrobitumen). The latter resulted from 
the secondary cracking of a former liquid oil phase which migrated into the larger paleo-intergranular pore spaces of the organically lean rocks of the Montney Fm. Sanei et al. (2015) also believe in previous oil-source rock correlation studies (Riediger et al., 1990a, 1990b) based on biomarker signatures and suggesting that all oils produced from Triassic rocks in the WCSB have been sourced either from the Doig Fm or the Nordegg Member of the Fernie Fm.

On the other hand, a study conducted by Romero-Sarmiento et al. (2016b) on core and cutting samples (partly falling close to wells $16-17$ and 12-36) led to the conclusion that the Montney Fm may contain potential source rock beds. Based on artificial thermal maturation, organic petrography and gas chromatography, these authors indicate that the samples represent a series from immature and early mature source rocks with preserved liptinite, to post-peak-mature and over-mature source and tight reservoir rocks containing abundant solid bitumen.

Montney lithologies from cores and cuttings distributed in a large area and encompassing well 16-17, were analyzed by Crombez et al. (2016) for organic content and for major and trace element concentrations. Their results illustrate that sequence 3 presents propitious redox conditions and primary productivity for source rocks development and emphasize the occurrence of primary deposited kerogen in this stratigraphic interval.

The presence of source-rock intervals in the Montney $\mathrm{Fm}$ is also supported by Feng et al. (2016, 2017), who identified three different oil families with distinct geochemical signatures within hydrocarbon accumulations of the Montney Fm. One of the oil family appears to be originated from the Montney Fm since it bears striking resemblance to the Montney rock extracts.

Finally, very recent studies also highlighted the presence of primary organic facies, coexisting with disseminated and pore-filling solid bitumen in the Montney Fm from Alberta (Ardakani et al., 2020; Becerra et al., 2020). These observations further call into question the possible local source the hydrocarbons within this formation. 
North-West of Fort St. John (i.e. in between the HRSZ and the inherited structure from the PRA collapse; Fig. 1A), may bring some light from independent observations to this controversy. In the samples here investigated, three different generations of veins were identified (Fig. 10), carrying different types of HC fluids (Table 3) and having different timing within the WCSB geological and geodynamic evolution (Fig. 15). Many of the studied veins are filled by calcite crystals with fibrous to blocky fibrous habitus in syntaxial to antitaxial arrangements and may display features of crack-seal mechanism (Fig. 10 and Tables S1a and S1b from Supplementary Material). This suggests that the mineral precipitation commonly occurred during vein opening (syn-kinematic calcite) so that the governed by Fe and Mn contents), together with the isotope composition, are very similar for all the studied calcite cements, irrespective of the well core of belonging, the vein generation and the crystal habitus/textures (Fig. 10 and 11). In conclusion, despite the different timing of the vein 895 calcites (Late Cretaceous to Paleogene), precipitating at different maturity stages of the HC system, 896 the calcite cements display similar petrographic and geochemical features (Fig. 10 and 11). This conclusively points at fluids in continuous equilibrium with the host-rocks (Hooker et al., 2017b, 2019). According to this scenario, the calcite veins identified probably formed as hydraulic fractures from a closed fluid system which would have persisted during the burial history of the studied lithologies. minerals within the studied samples (Fig. 7). This contrasts with the occurrence of anhydrite and barite in samples from well cores located South of Fort St. John (within the inherited structure from the PRA collapse; Liseroudi et al., 2020), and which is interpreted as due to the contribution of externally sourced paleo-waters (i.e. sulfate-bearing fluids originated from the dissolution of underlying Devonian evaporites and migrated upwards through deep-seated faults/fractures to the 
in the Montney-Doig system throughout the WCSB and deciphering between migrated and in place hydrocarbons in these lithologies at basin scale is far beyond our scopes. Nevertheless, this study clearly suggests that, at least in the limited portion of the basin investigated, the advection of externally sourced paleo-waters (sensu McCaig and Knipe, 1990) was not recorded during the precipitation of calcites within the three fracture generations identified (Fig. 15). The lack of evidence characterized by a closed-system hydrodynamic regime, at least during the Late Cretaceous to Paleogene evolution of the basin. This may have important implications for future exploration.

\section{CONCLUSIONS}

A multidisciplinary approach (including sedimentology, Rock-Eval pyrolysis, petrography, O-CSr isotope geochemistry and fluid inclusion microthermometry) has been applied for the first time to natural mineralized fractures (veins) hosted by mudrocks of the Lower-Middle Triassic Montney-Doig unconventional resource play from the Western Canada Sedimentary Basin. variable mineralogy and organic content (TOC of 0.6 to $6.6 \mathrm{wt} \%)$.

1) Fracture occurrence was chiefly controlled by host-rock facies and only to a minor extent by host-rock diagenesis. Horizontal (bed-parallel) fractures are preferentially localized in very 
fine facies (siltstones and siltstones with clays) of the offshore environment and where high frequency facies changes induced vertical heterogeneities. Vertical to high angle fractures are more abundant in the coarser facies of the offshore transition environment (coarse siltstones and fine sandstones), though theymay also occur in offshore facies (e.g. calcispheric dolosiltstones) which have undergone burial dolomitization. Interestingly, hostrock TOC seems not to have controlled fracture occurrence.

2) Three generations of calcite cemented fractures were identified: carrying oil inclusions, records that oil generation had begun; they possibly opened when vertical movements of the foreland were limited and rapid sedimentation of the Colorado Group occurred (Late Cretaceous).

- The second generation (horizontal veins), cemented by calcite carrying $\mathrm{CH}_{4} \pm \mathrm{CO}_{2}$ inclusions, originated during peak $\mathrm{HC}$ generation; they possibly opened just before maximum burial (Late Cretaceous - Early Paleogene) as a result of overpressures induced by $\mathrm{CH}_{4}$ generation, assisted by compressive horizontal stress. Fairly distributed fluid overpressures throughout the succession would explain why they principally developed in the more brittle lithologies, rather than in the OM-rich intervals.

- The third generation (vertical veins), cemented by calcite also containing $\mathrm{CH}_{4} \pm \mathrm{CO}_{2}$ inclusions, possibly opened during basin uplift (Middle-Late Paleogene) due to horizontal stress decrease, assisted by residual fluid (gas) overpressure.

3) UV-light and CL response of the calcite cements together with their isotope geochemistry signature are quite consistent, irrespective of the vein generation and well core of belonging, pointing at lack of evidences for externally sourced paleo-waters. This suggests a closed system behavior for the studied rocks during Late Cretaceous - Paleogene times, at least in the limited portion of the basin investigated. 
Overall the study underlines the relevance and usefulness of the applied methodological

958

959

960

961

962

963

964

965

966

967

968

969

970

971

972

973

974

975

976

977

978

979

980

approach to characterize fracture controls, paleo-fluid circulation and openness of the fluid system in naturally fractured unconventional plays, with implications for exploration.

\section{ACKNOWLEDGEMENTS}

The core-lab of the BC Oil \& Gas Commission from Fort St. John is thanked for assistance during core logging and sampling. We are grateful to W. Sassi (head of the "non-conventional gas" project at IFP Energies nouvelles) for funding the whole survey and for scientific advice during its preliminary stages. The ISTeP laboratory (Sorbonne Université) is acknowledged for funding a 5 months internship of M. Belkacemi at IFP Energies nouvelles. D. Pillot (IFP Energies nouvelles) helped with the Rock-Eval measurements and interpretation. We acknowledge Marc Enter and Matthew Power from SGS (now at Vidence Inc.), for providing the Qemscan data of well 12-36. Prof. M. Joachimski (GeoZentrum Nordbayern) is thanked for O-C isotope analysis of calcites. The SUERC laboratory is thanked for ${ }^{87} \mathrm{Sr} /{ }^{86} \mathrm{Sr}$ analysis of calcites. The authors also wish to thank the two reviewers (Kitty L. Milliken and John N. Hooker) for their constructive comments that allowed significant improvement of the manuscript.

\section{FIGURE CAPTIONS}

Fig. 1. Geographic and geological setting of the study area. A. Geological map of the Canadian segment of the Cordillera including the main belts and terranes, and the Western Canada Sedimentary Basin (WCSB). The purple color shows the subcrop and outcrop areas where Triassic deposits are still preserved (simplified from Rohais et al., 2018 and references herein). The Hay River Shear Zone (HRSZ) and the inherited structure from the Paleozoic Peace River Arch (PRA) collapse are 
981

982

highlighted as main structural elements below the Triassic strata. (1) and (2) refer to the wells investigated, localized in between these two main structural domains. The black dotted line represents the trace of a cross-section (illustrated in B). B. Cross-section of the WCSB illustrating the main stratigraphic intervals and the faults (simplified from Ducros et al., 2017).

Fig. 2. Simplified sedimentary architecture and main stratigraphic sequences of the Lower and Middle Triassic of the WCSB (modified after Crombez et al., 2019).

Fig. 3. Simplified stratigraphy of the two investigated wells including the gamma ray response and sequences, the TOC and MinC from Rock-Eval (by merging data from this study and from Crombez et al., 2016), the facies associations (in yellow) and their interpretation in terms of depositional environments (in green), as well as the location of the observed fractures with their orientation. See Table 1 for the legend of numerical codes used to define the different facies associations and depositional environments.

Fig. 4. Reconstructed depositional profile for the Montney-Doig interval with main facies associations and microfacies petrographic images (in PPL) for some of them. 1. Lag; 2. Massive fine-grained sandstones; 3 . Massive very fine-grained sandstones to siltstones; 4 . Sand-dominated alternation of very fine-grained sandstones to siltstones; 5 . Silt-dominated alternation of very fine-grained sandstones to siltstones; 6. Massive siltstones; 7. Organic-rich massive siltstones; 8 . Bioclastic siltstones; 9. Laminated siltstones with mm-thick sand laminae (low density turbidite); 10. Laminated siltstones. 
1004

1005

1006

1007

1008

1009

1010

1011

1012

1013

1014

1015

1016

1017

1018

1019

1020

1021

1022

1023

1024

Fig. 5. Frequency distribution of TOC values (in wt. \%) from the two investigated wells according to two different datasets: 1) continuous sampling of cores and cuttings from Crombez et al. (2016), in black; 2) core samples hosting fractures from this study, in grey.

Fig. 6. Petrographic photos illustrating the main carbonate diagenetic phases occurring in the studied samples of the Montney-Doig Fms. A. Euhedral to sub-hedral D1 crystals with dull orange CL totally or partially replacing detrital dolomite grains (sample 16-17-21). B. D2 crystals with bright red CL locally forming overgrowths around detrital grains replaced by D1 (sample 16-17-23). C. Facies with calcispheres from the offshore environment (sample 16-17-21). PPL. D. Same image of C. under CL. Calcispheres are replaced by the ferroan and non-luminescent D3. E. C2 crystals with bright orange CL occurs as cement in intergranular pores or as replacement of calcispheres (sample 1236-C3-6). F. $\mathrm{C} 2$ with bright orange $\mathrm{CL}$ occurs as cement in intergranular pores or replaces previous carbonate phases (sample 1617-15). PPL= plane polarized light, $\mathrm{CL}=$ cathodo luminescence.

Fig. 7. Paragenetic sequence reconstructed for the Montney-Doig Fms in this study as compared with the one from Vaisblat et al. (2017b). In black the phases that were observed in both studies; in blue the phases that were observed only by Vaisblat et al. (2017b); in red the phases that were observed only in this study. Black arrows indicate the four most abundant carbonate diagenetic phases.

Fig. 8. Well core pieces containing macroscopic mineralized fractures (i.e. veins). A. Horizontal vein from well $12-36$ at $2364.3 \mathrm{~m}$ of depth. B. Vertical vein from well $16-17$ at $2350 \mathrm{~m}$ of depth. 
Fig. 9. Frequency distribution of the properties FRACTURE, SEQUENCE, ENVIRONMENT and TOC from 16-17 and 12-36 well cores based on the sampled points reported in the spreadsheets of Tables S3a and S3b (see Supplementary Material). The red line represents the distribution of the whole sampled points where fractures occur (i.e. only the points with codes 2 and 3 of the property FRACTURE). The black bars in the upper (A) and lower (B) histograms representthe sampled points corresponding respectively to the occurrence of the horizontal and vertical to high angle fractures. The " 777 " values are attributed to cells of the spreadsheets where information on a given property was not available. In the histograms to the right (property TOC) the " 777 " sampled points represent $~ 80 \%$ of the total. See Table 1 for code explanation.

Fig. 10. Photomicrographs of cemented fractures (i.e. veins) from the $16-17$ and 12-36 wells. All images are oriented with the upper part of the photos corresponding to the stratigraphic up direction. $\mathrm{PPL}=$ plane polarized light, $\mathrm{CPL}=$ crossed-polarized light, $\mathrm{CL}=$ cathodoluminescence. $\mathbf{A}$. Vertical vein filled by blocky calcite crystals (sample 16-17-23). PPL. B. Same image of A. under CL. The blocky calcite shows uniform, bright orange luminescence. C. Horizontal vein filled by fibrous to elongated blocky calcite crystals with antitaxial arrangement. Median planes are highlighted by yellow dotted lines. Crystal deformation suggests mixed mode I-mode II vein opening (sample 12-36C3-2). CPL. D. Same image of C. under CL. The crystals have dominantly bright orange luminescence. Some of them may evolve from bright to dull orange during growth. E. Horizontal vein filled by elongated blocky to blocky calcite crystals displaying incremental growth by crack-seal episodes, highlighted (yellow arrows) by strings of wall rock inclusions, demonstrating mode I vein opening (sample 16-17-2). PPL. F. Same image of E. under CL. The crystals show uniform bright orange luminescence. G. Vertical vein filled by blocky calcite crystals replacing blocky (locally elongated blocky) calcite crystals filling an horizontal vein as highlighted by the yellow dotted line (sample 12- 
1050

1051

1052

1053

1054

1055

1056

1057

1058

1059

1060

1061

1062

1063

1064

1065

1066

1067

1068

1069

1070

1071

1072

36-C2-2B). CPL. H. Same image of G. under CL. The calcite crystals filling the different veins show undistinguishable uniform bright orange luminescence.

Fig. 11. O-C stable isotope composition of the fracture sealing calcite cements. The vein orientation (horizontal or vertical to high angle) and the stratigraphic sequence of belonging are reported. The O-C isotope composition of calcites precipitated in equilibrium from Early Triassic seawater (from Veizer et al., 1999) is represented by the light blue squares. A. Calcite veins from well 16-17. B. Calcite veins from well 12-36.

Fig. 12. Photomicrographs illustrating some petrographic features of the analyzed Fls at room temperature. A. Assemblages of possibly primary Type I Fls (yellow arrows) occurring in the core of calcite crystals (vertical vein, sample 16-17-23). B. Details of assemblage of Type I Fls from the same sample illustrated in A. C. Assemblage of possibly primary Type II Fls occurring in the calcite crystal cores (vertical vein, sample 16-17-23). D. Same image of C. under UV-light revealing a bright green fluorescence for the Type II FIs. E. Assemblage of possibly primary Type IV FIs displaying shapes from negative crystal to crystallographically controlled (horizontal vein, sample 12-36-C2-2B). F. Same image of E. under UV-light revealing a week green fluorescence for some of the Type IV FIs.

Fig. 13. Results of microthermometry for primary Fls in calcite cements from differently oriented veins. A. Frequency distribution of Th values for Type I and Type II Fls (sample 16-17-23, vertical vein). The red bar refers to possibly reequilibrated Type I FIs. B. Frequency distribution of Tmi values for Type I Fls (sample 16-17-23, vertical vein). C. Frequency distribution of Th values for Type IV FIs (sample 12-36-C2-2B, horizontal and vertical veins). D. Frequency distribution of Th values for Type II 


\section{Journal Pre-proof}

1073

1074

1075

1076

1077

1078

1079

1080

1081

1082

1083

1084

1085

1086

1087

1088

1089

1090

and Type IV Fls (sample 12-36-C1-4, horizontal vein). Light and dark grey bars refer to horizontal and vertical veins respectively.

Fig. 14. Results of this study (facies associations, depositional environments, TOC, location and orientation of fractures) for the three cores (core 1, core 2, core 3) of well 12-36 are reported together with data from literature: mineralogy (from British Columbia Oil \& Gas Commission) and brittleness (from Chatellier et al., 2018). High values of brittleness are in red, low values in blue, intermediate values are in green. Mineralogy data are available for core 1 and core 3 only. Red horizontal lines highlight the horizontal fractures. See figure 3 for location of the cores along well 1236.

Fig. 15. Thermal evolution of the Montney-Doig Fms, from deposition to present day, modeled with TemisFlow $^{\mathrm{TM}}$ by considering $3300 \mathrm{~m}$ of eroded sediments during Tertiary uplift (Ducros et al., 2017). The main stages of the basin evolution are reported together with the possible time-temperature frame for the three generations of veins: first vertical generation (blue arrow), second horizontal generation (red arrow), third vertical generation (yellow arrow). 
1092 Table 1. Tables summarizing the codes attributed to the main properties (i.e. sequence, facies 1093 associations, depositional environments, fracture occurrence) recorded along the logs of the studied 1094 well cores. These codes were used for frequency distribution analysis with EasyTrace ${ }^{\mathrm{TM}}$ software.

1095

1096 Table 2. Range and mean TOC and HI values from bulk-rock Rock-Eval measurements for the 1097 investigated samples by sequence and well core of belonging.

1098

1099 Table 3. Results of Fl study from wells $12-36$ and 16-17. Sample name, fracture orientation, texture 1100 of the sealing calcite phases, type and petrographic occurrence of fluid inclusions (FI), type of fluid 1101 phases and their response under UV-light are reported, together with the range and mode values of 1102 homogenization temperatures (Th), ice melting temperatures (Tmi) and calculated salinity. 
1105

1106

1107

1108

1109

1110

1111

1112

1113

1114

1115

1116

1117

1118

1119

1120

1123

1124

1125

1126

Table S1a. Details on investigated samples from well core 16-17, including sample name, depth, sequence of provenance, depositional environment, number of fractures, their orientation and kinematic aperture, texture of the sealing calcites and their O-C-Sr isotope composition. In some samples, O-C isotope analysis were performed for different veins or for different calcite textures occurring in the same vein.

Table S1b. Same as in Table S1a for the samples from well core 12-36.

Table S2a. Details on samples from well core 16-17, including sample name, depth, sequence of provenance, depositional environment and the parameters obtained from Rock-Eval analysis accomplished with the Shale Play Method ${ }^{\circledR}$ developed at IFP Energies nouvelles (Pillot et al., 2014; Romero-Sarmiento et al., 2016a, 2016b): Sh0, Sh1, Sh2, Tmax, TOC, HI, OI, HCcont, MinC. TOC= total organic carbon, $\mathrm{HI}=$ hydrogen index, $\mathrm{Ol}=$ oxygen index, $\mathrm{HCcont}=$ content in hydrocarbons, $\mathrm{MinC}=$ mineral carbon. Column names with $-B$ and $-E$ refer to analyses performed on bulk-rock and extracted organic matter, respectively.

Table S2b. Same as in Table S2a for the samples from well core 12-36.

Table S3a. Spreadsheet for well core 16-17 with the evolution of different properties with depth used for frequency distribution analysis with Easytrace ${ }^{\mathrm{TM}}$ software. The properties considered are: presence/absence of fractures (i.e. FRACTURE), the stratigraphic sequence (i.e. SEQUENCE), the depositional environment (i.e. ENVIRONMENT), the TOC values (i.e. TOC). Each line of the table 


\section{Journal Pre-proof}

1127 represents a point virtually sampled along the log of well 16-17 to which information on the different

1128 properties were attributed via numerical codes (see Table 1). As requested by the software, the value

1129 "777" was attributed to the cells where information for a given property was not available.

1130 Table S3b. Same as in Table S3a for well core 12-36. 
Aoudia, K., Miskimins, J. L., Harris, N. B., Mnich, C.A., 2010. Statistical analysis of the effects of

mineralogy on rock mechanical properties of the Woodford shale and the associated impacts for

hydraulic fracture treatment design. In 44th US Rock Mechanics Symposium and 5th US-Canada Rock

Mechanics Symposium. American Rock Mechanics Association.

Ardakani, O.H., Hlohowskyj, S.R., Chappaz, A., Sanei, H., Liseroudi, M.H., Wood, J.M., 2020.

Molybdenum speciation tracking hydrocarbon migration in fine-grained sedimentary rocks,

Geochimica et Cosmochimica Acta. DOI: 10.1016/j.gca.2020.06.006

Clarkson, C.R., 2020. Organic matter in the Alberta Montney re-visited: evidence for primary organic

J.H., 1962. Triassic oil and gas occurrences in northeastern British Columbia, Canada. Bulletin of

isotope stratigraphy: whole rock analysis. Chemical Geology 167, 313-319. DOI:10.1016/S00092541(99)00235-1

Birck, J.L., 1986. Precision K-Rb-Sr isotopic analysis: Application to Rb-Sr chronology. Chemical Geology 56, 73-83. DOI:10.1016/0009-2541(86)90111-7

Beaudoin, N., Lacombe, O., Roberts, N.M., Koehn, D., 2018. U-Pb dating of calcite veins reveals 1015-1018.

Becerra, D., Clarkson, C.R., Ghanizadeh, A., Ardakani, O.H., 2020. First-Time Characterization of 
Bjørlykke, K., 1994. Fluid-flow processes and diagenesis in sedimentary basins. In: Geofluids:

1158

Origin, Migration and Evolution of Fluids in Sedimentary Basins, Ed. J. Parnell, Geological Society, London, Special Publications, Volume 78, 127-140. DOI: 10.1144/GSL.SP.1994.078.01.11

Bjørlykke, K., Jahren, J., 2012. Open closed geochemical systems during diagensis in sedimentary basins: Constraints on mass transfer during diagenesis and the prediction of porosity in sandstone and carbonate reservoirs. AAPG Bulletin, 96 (12), 2193-2214. DOI:10.1306/04301211139 Bodnar, R.J., 1993. Revised equation and table for determining the freezing point depression of $\mathrm{H}_{2} \mathrm{O}-\mathrm{NaCl}$ solutions. Geochimica et Cosmochimica Acta, 57(3), 683-684.

Bons, P.D., Elburg, M.A., Gomez-Rivas, E., 2012. A review of the formation of tectonic veins and their microstructures. Journal of Structural Geology, 43, 33-62.

Chatellier, J.-Y., Simpson, K., Perez, R., Tribovillard, N., 2018. Geochemically focused integrated approach to reveal reservoir characteristics linked to better Montney productivity potential. Bulletin of Canadian Petroleum Geology, 66(2), 516-551.

Chalmers, G.R., Bustin, R.M., 2012. Geological evaluation of Halfway-Doig-Montney hybrid gas shale-tight gas reservoir, northeastern British Columbia. Marine and Petroleum Geology, 38, 53-72. Cobbold, P.R., Zanella, A., Rodrigues, N., Løseth, H., 2013. Bedding-parallel fibrous veins (beef and cone-in-cone): Worldwide occurrence and possible significance in terms of fluid overpressure, hydrocarbon generation and mineralization. Marine and Petroleum Geology, 43, 1-20.

Conliffe, J., Burden, E.T., Wilton, D.H., 2017. The use of ntegrated fluid inclusion studies for constraining petroleum charge history at Parsons Pond, Western Newfoundland, Canada. Minerals, 7(3), 39.

Creaney, S., Allan, J., 1990. Hydrocarbon generation and migration in the Western Canada Sedimentary Basin, in Brooks, J., eds., Classic Petroleum Provinces, Geological Society Special Publication, 50, 189-202.

Crombez, V. 2016. Petrofacies, sedimentology and stratigraphic architecture of organic rich rocks. Insights from a multi- disciplinary study of the Montney and Doig Formations (Lower and 
Middle Triassic, Alberta - British Columbia, Canada). PhD thesis, Paris VI University, 238 p., IFPEN report 66669.

Crombez, V., Baudin, F., Rohais, S., Riquier, L., Euzen, T., Pauthier, S., Ducros, M., Caron, B., Vaisblat, N., 2016. Basin scale distribution of organic matter in marine fine grained sedimentary rocks: Insight from sequence stratigraphy and multi-proxies analysis in the Montney and Doig formations. Marine and Petroleum Geology, 83, 382-401.

Crombez, V., Rohais, S., Baudin, F., Euzen, T., Zonneveld, J.-P., Power, M., 2019. 3D stratigraphic architecture, sedimentary budget, and sources of the Lower and Middle Triassic strata of Western Canada: evidence for a major basin structural reorganization". Petroleum Geoscience. DOI: 10.1144/petgeo2019-024

Curtis, J.B., 2002. Fractured shale-gas systems. AAPG Bulletin, 86(11), 1921-1938.

Davies, G.R., 1997. The Triassic of the Western Canada Sedimentary Basin tectonic and stratigraphic framework, paleogeography, paleoclimate and biota. Bulletin of Canadian Petroleum Geology, 45, 434-460.

Davies, G.R., Moslow, T.F., Sherwin, M. D., 1997. The lower Triassic Montney formation, westcentral Alberta. Bulletin of Canadian Petroleum Geology, 45(4), 474-505.

Davies, G.R., Hume, D., Fox, A., Haysom, S., Nevokshonoff, G., Reinmiller, R., 2014. Core-based structural fabrics in mudstones of the WCSB: 'PSF' and cleavage. Unconventional Resources Technology Conference, August 25-27, Denver, CO, USA.

Davies, G.R., Watson, N., Moslow, T.F., MacEachern, J.A., 2018. Regional subdivisions, sequences, correlations and facies relationships of the Lower Triassic Montney Formation, westcentral Alberta to northeastern British Columbia, Canada - with emphasis on role of paleostructure. In: T. Euzen, T.F. Moslow and M. Caplan, eds., The Montney Play: Deposition to Development. Bulletin of Canadian Petroleum Geology, 66(1), 23-92. 
Day-Stirrat, R.J., Milliken, K.L., Dutton, S.P., Loucks, R.G., Hillier, S., Aplin, A.C., Schleicher, A.M.,

1208

1209

1210

1211

1212

1213

1214

1215

1216

1217

1218

1219

1220

1221

1222

1223

1224

1225

1226

1227

1228

1229

1230

1231

2010. Open-system chemical behavior in deep Wilcox Group mudstones, Texas Gulf Coast, USA. Marine and Petroleum Geology 27, 1804-1818.

Dawson, M., Kalkreuth, W., 1994. Coal rank and coalbed methane potential of Cretaceous/Tertiary coals in the Canadian Rocky Mountain foothills and adjacent foreland: 1. Hinton and Grande Cache areas, Alberta. Bulletin of Canadian Petroleum Geology, 42(4), 544-561.

DeCelles, P.G., 2004. Late Jurassic to Eocene evolution of the Cordilleran thrust belt and foreland basin system, western USA. American Journal of Science, 304, 105-168, DOI:

10.2475/ajs.304.2.105

Deschamps, R., Kohler, E., Gasparrini, M., Durand, O., Euzen, T., Nader, F.H., 2012. Impact of mineralogy and diagenesis on reservoir quality of the Lower Cretaceous Upper Mannville Formation (Alberta, Canada). Oil \& Gas Science and Technology, 67(1): 31-58. DOI: 10.2516/ogst/2011153

Dewhurst D.N., Yang Y., Aplin A.C., 1999. Permeability and fluid flow in natural mudstones. Geological Society, London, Special Publications, 158, 23-43.

Dickson, J.A.D., 1966. Carbonate identification and genesis as revealed by staining. Journal of Sedimentary Research, 36(2), 491-505.

Ding, W., Li, C., Li, C., Xu, C., Jiu, K., Zeng, W., Wu, L., 2012. Fracture development in shale and its relationship to gas accumulation. Geoscience Frontiers, 3, 1, 97-105.

Dixon, J., 2000. Regional lithostratigraphic units in the Triassic Montney Formation of western Canada. Bulletin of Canadian Petroleum Geology, 48, 80-83.

Dong, T., Harris, N.B., Ayranci, K., Yang, S., 2017. The impact of rock composition on geomechanical properties of a shale formation: middle and upper devonian Horn River Group shale, northeast British Columbia, Canada. AAPG Bull., 101, 177-204.

Dong, T., Harris, N.B., Knapp, L.J., McMillan, J.M., Bish, D.L., 2018. The effect of thermal maturity on geomechanical properties in shale reservoirs: An example from the Upper Devonian 
Duvernay Formation, Western Canada Sedimentary Basin. Marine and Petroleum Geology, 97, 137153.

Ducros, M., Sassi, W., Vially, R., Euzen, T., Crombez, V., 2017. 2-D Basin Modeling of the Western Canada Sedimentary Basin across the Montney-Doig System: Implications for Hydrocarbon Migration Pathways and Unconventional Resources Potential, in Mahdi A. AbuAli, Isabelle Moretti, and Hege M. Nordgård Bolås, eds., Petroleum Systems Analysis-Case Studies. AAPG Memoir 114, 117-134.

Ejezie, N., 2007. Triassic Oil Families and Possible Source Rocks, Peace River Embayment Area, Alberta, Canada. Master Thesis, University of Calgary, Alberta, Canada, 393 p.

Engelder, T., Fischer, M.P., 1994. Influence of poroelastic behavior on the magnitude of minimum horizontal stress, Sh in overpressured parts of sedimentary basins. Geology, 22(10), 949952.

Engelder, T., Peacock, D.C., 2001. Joint development normal to regional compression during flexural-flow folding: the Lilstock buttress anticline, Somerset, England. Journal of Structural Geology, 23(2-3), 259-277.

Engelder, T., Lash, G.G., Uzcátegui, R.S., 2009. Joint sets that enhance production from Middle and Upper Devonian gas shales of the Appalachian Basin. AAPG bulletin, 93(7), 857-889.

Euzen, T., Moslow, T.F., Crombez, V., Rohais, S. 2018. Regional stratigraphic architecture of the Spathian deposits inWestern Canada - Implications for the Montney resource play. In: Euzen, T., Moslow, T.F. \& Caplan, M. (eds), The Montney Play of Western Canada: Deposition to Development. Bulletin of Canadian Petroleum Geology, 66, 175-192.

Euzen, T., Watson, N., Fowler, M., Mort, A., Moslow, T.F., in press. Petroleum distribution in the Montney hybrid play: source, carrier bed and structural controls. AAPG Bulletin.

Fantle, M.S., Maher, K.M., DePaolo, D.J., 2010. Isotopic approaches for quantifying the rates of marine burial diagenesis. Rev. Geophys., 48, RG3002. DOI:10.1029/2009RG000306. 
Faure, J.L., Osadetz, K., Benaouli, Z.N., Schneider, F., Roure F., 2004. Kinematic and Petroleum

Modeling of the Alberta Foothills and Adjacent Foreland - West of Calgary, Oil Gas Sci. Technol. Rev. IFP, 59(1), 81-108.

Feng, W., Chen, Z., Jiang, C., 2016. Oil and source correlations of Triassic Montney Formation in WCSB: implication to shale gas resource potential. Geoconvention, Calgary, March 2016.

Feng, W., Chen, Z., Jiang, C., Harris, N., 2017. Volumetric method to determine the contribution of Montney sourced hydrocarbons to the Montney and Doig petroleum system. Geoconvention, Calgary, March 2017.

Ferri, F., Zonneveld, J.P., 2008. Were Triassic rocks of the Western Canada Sedimentary Basin deposited in a foreland. Canadian Society of Petroleum Geologists Reservoir, 35(10), 12-14.

Ferrill D.A, Morris P., Evans M.A., Burkhard M., Groshong R.H.,Onasch C.M., 2004. Calcite twin morphology: a low-temperature deformation geothermometer. J. Struct. Geol. 26, 8, 1521-1529.

Fuentes, F., DeCelles, P.G., Constenius, K.N., Gehrels, G.E., 2011. Evolution of the Cordilleran foreland basin system in northwestern Montana, U.S.A. Geological Society of America Bulletin, 123, 507-533. DOI: 10.1130/B30204.1

Fuentes, F., DeCelles, P.G., Constenius, K.N., Gehrels, G.E., 2011. Evolution of the Cordilleran foreland basin system in northwestern Montana, U.S.A. Geological Society of America Bulletin, 123, 507-533, DOI: 10.1130/B30204.1

Furlong, C.M., Gingras, M.K., Moslow, T.F., Zonneveld, J.P., 2018. The Sunset Prairie Formation: designation of a new Middle Triassic formation between the Lower Triassic Montney Formation and Middle Triassic Doig Formation in the Western Canada Sedimentary Basin, northeast British Columbia. Bulletin of Canadian Petroleum Geology, 66(1), 193-214.

Furlong, C.M., Gegolick, A., Gingras, M.K., González, P., Moslow, T.F., Prenoslo, D., Playter, T., Zonneveld, J.P., 2018. Sedimentology and ichnology of the Middle Triassic (Anisian) Sunset Prairie Formation of the Western Canada Sedimentary Basin. Bulletin of Canadian Petroleum Geology, 66(1), 215-236. 
Gabellone, T., Gasparrini, M., Iannace, A., Invernizzi, C., Mazzoli, S., D'Antonio, M., 2013. Fluid

1284

1285

1286

1287

1288

1289

1290

1291

1292

1293

1294

1295

1296

1297

1298

1299

1300

1301

1302

1303

1304

1305

1306

1307

1308

channelling along thrust zones: the Lagonegro case history, Southern Apennines, Italy. Geofluids, 13(2): 140-158. DOI: $10.1111 / \mathrm{gfl} .12020$

Gale J.F.W., Reed R.M., Holder J., 2007. Natural fractures in the Barnett Shale and their importance for hydraulic fracture treatments. AAPG Bulletin, 91, 4, 603-622

Gale J.F.W., Laubach S.E., Olson J.E., Eichhubl P., Fall A., 2014. Natural fractues in shale: A review and new observations. AAPG Bulletin, 98, 11, 2165-2216

Gale, J.F.W., Holder, J., 2010. Natural fractures in some US shales and their importance for gas production. In: Geological Society, London, Petroleum Geology Conference Series, vol. 7, 1131-1140. DOI: 10.1144/0071131.

Gasparrini M., Sassi W., Gale J.F.W., 2014. Natural sealed fractures in mudrocks: A case study tied to burial history from the Barnett Shale, Fort Worth Basin, Texas, USA. In : Fluid-rock-tectonics interactions in basins and orogens, Special Issue, Lacombe O., Swennen R. and Caracausi A. (eds). Marine and Petroleum Geology, 55, 122-141. DOI: 10.1016/j.marpetgeo.2013.12.006

Gasparrini, M., López-Cilla, I., Blázquez-Fernández, S., Rosales, I., Lerat, O., Martín-Chivelet, J., Doligez, B., 2017. A multidisciplinary modeling approach to assess facies-dolomitization-porosity interdependence in a Lower Cretaceous platform (northern Spain). In: MacNeil, A.J., Lonnee, J., Wood, R. (eds), "Characterization and Modeling of Carbonates-Mountjoy Symposium 1", SEPM Special Publication 109: 130-153. SEPM (Society for Sedimentary Geology), Tulsa, Oklahoma. DOI: 10.2110/sepmsp.109.07

Ghanizadeh A., Clarkson C.R., Aquino S., Ardakani O.H., Sanei H., 2015. Petrophysical and geomechanical characteristics of Canadian tight oil and liquid-rich gas reservoirs: I. Pore network and permeability characterization. Fuel, 153, 664-681.

Ghanizadeh A., Clarkson C.R., Aquino S., Ardakani O.H., Sanei H., 2015. Petrophysical and geomechanical characteristics of Canadian tight oil and liquid-rich gas reservoirs: II. Geomechanical property estimation. Fuel, 153, 682-691. 
Gillen, K., Wood, J.M, Sharp, L., Grimison, T., Guerard, B., 2019. Natural and Induced Structural

1310 Fabrics in Drill Cores from the Montney Formation, New Directions in Geosciences for

Unconventional Resources, 2019 William C. Gussow Geoscience Conference, Calgary, Alberta, 15-17 Ocrober, 2019.

Gillespie, J.M., Heller, P.L., 1995. Beginning of foreland subsidence in the Columbian-Sevier

belts, southern Canada and northwest Montana: Geology, 23, 723-726. DOI: 10.1130/0091-

Golding, M.L., Orchard, M.J., Zonneveld, J.P., Wilson, N.S F., Reinson, G., 2015. Determining the

age and depositional model of the Doig Phosphate Zone in northeastern British Columbia using conodont biostratigraphy. Bulletin of Canadian Petroleum Geology, 63(2), 143-170.

Hans, U., Kleine, T., Bourdon, B., 2013. Rb-Sr chronology of volatile depletion in differentiated

protoplanets: BABI, ADOR and ALL revisited. Earth and Planetary Science Letters 374, 204-214.

doi:10.1016/j.epsl.2013.05.029

Hansman, R.J., Albert, R., Gerdes, A., Ring, U., 2018, Absolute ages of multiple generations of brittle structures by U-Pb dating of calcite. Geology, 46, 207-210.

Hardebol, N., Callot, J.-P., Bertotti, J.L., Faure, J.L., 2009. Sedimentary and tectonic burial history appraisal and consequent temperature and organic maturation evolution in thrust-belt systems: a study on the SE Canadian Cordillera. Tectonics, 28, TC3003, DOI: 10.1029/2008TC002 Higley, D.K., Henry, M.E., Roberts, L.N.R., 2005. Petroleum System Modeling of the Western Canada Sedimentary Basin-Isopach Grid Files. US Geological Survey. Open-File Report 2005-1421. DOI: $10.3133 /$ ofr20051421 geobarometry by combining fluid inclusion and clumped isotope $\left(\Delta_{47}\right)$ thermometry in hydrothermal carbonates. Terra Nova, 30(3): 199-206. DOI: 10.1111/ter.12326 
Hooker, J.N., Cartwright, J., Stephenson, B., Silver, C.R.P., Dickson, A.J., Hsieh, Y.-T., 2017b.

1336

1337

1338

1339

1340

1341

1342

1343

1344

1345

1346

1347

1348

1349

1350

1351

1352

1353

1354

1355

1356

1357

1358

1359

1360

Fluid evolution in fracturing black shales, Appalachian Basin. AAPG Bull. 101(8), 1203-1238.

DOI:10.1306/10031616030

Hooker, J.N., Abu-Mahfouza, I.S., Meng, Q., Cartwright, J., 2019. Fractures in mudrocks:

Advances in constraining timing and understanding. Journal of Structural Geology 125, 166-173. DOI:

10.1016/j.jsg.2018.04.020

Hooker, J.N., Ruhl, M., Dickson, A.J., Hansen, L.N., Idiz, E., Hesselbo, S.P., Cartwright, J., 2020.

Shale anisotropy and natural hydraulic fracture propagation: An example from the Jurassic (Toarcian)

Posidonienschiefer, Germany. Journal of Geophysical Research: Solid Earth, 125, e2019JB018442.

https://doi.org/10.1029/2019JB018442Hu, Y., Gonzalez Perdomo, M.E., Wu, K., Chen, Z., Zhang, K., Yi, J., Guoxian, R., Yu, Y., 2015. New models of brittleness index for shale gas reservoirs: weights of brittle minerals and rock mechanics parameters. In SPE Asia Pacific Unconventional Resources Conference and Exhibition. Society of Petroleum Engineers. DOI: 10.2118/177010-MS

Ibrahimbas, A., Riediger, C.L., 2004. Hydrocarbon source rock potential as determined by RockEval 6/TOC pyrolysis, NEBC and NW Alberta: Resource Development and Geoscience Branch, Summary of activities 2004: British Columbia Ministry of Energy and Mines, 7-17: http://www. empr. gov. bc. ca/OG/oilandgas/petroleumgeology/ConventionalOilAndGas.

Ilgen, A.G., Heath, J.E., Akkutlu, I.Y., Bryndzia, L.T., Cole, D.R., Kharaka, Y.K., Kneafseyg, T.J., Millikenh, K.L., Pyrak-Noltei, L.J., Suarez-Rivera, R., 2017. Shales at all scales: Exploring coupled processes in mudrocks. Earth-Science Reviews, 166, 132-152.

Jarvie, D.M., Hill, R.J. , Ruble, T. E., Pollastro, R.M., 2007. Unconventional shale-gas systems:

The Mississippian Barnett Shale of north-central Texas as one model for thermogenic shale-gas assessment. AAPG Bulletin, 91, 475-499.

Jochum, J., Friedrich, G., Leythaeuser, D., Littke, R., Ropertz, B., 1995. Hydrocar bonbearing fluid inclusions in calcite-filled horizontal fractures from mature Posidonia Shale (Hils Syncline, NW Germany). Ore Geol. Rev. 9, 363-370. 
Khalifa, M., Gasparrini, M., 2014. Open versus closed mesogenetic systems in Cretaceous tidal and fluvial sandstones, Sirt Basin, Libya. GeoArabia, 19(4), 113-140.

Kyser, T.K., Hiatt, E.E., Renac, C., Durocher, K., Holk, G.J., Deckart, K., 2000, Diagenetic fluids in paleo- and meso-Proterozoic sedimentary basins and their implications for long protracted fluid histories. In Kyser, K., (ed.) Fluids and Basin Evolution, Mineralogical Association of Canada, Ottawa, Canada, 262, 225-262. DOI: 10.13140/2.1.1033.1847

Labani, M.M., Rezaee, R., 2015. The importance of geochemical parameters and shale composition on rock mechanical properties of gas shale reservoirs: A case study from the Kockatea Shale and Carynginia Formation from the Perth Basin, Western Australia. Rock Mechanics and Rock Engineering, 48(3), 1249-1257.

Lacombe O., 2010, Calcite twins, a tool for tectonic studies in thrust belts and stable orogenic forelands. Oil and Gas Science and Technology, Rev. IFP, 65(6), 809-838.

Liseroudi, M.H., Ardakani, O.H., Sanei, H., Pedersen, P.K., Stern, R.A. Wood, J.M., 2020. Origin of sulfate-rich fluids in the Early Triassic Montney Formation, Western Canadian Sedimentary Basin. Marine and Petroleum Geology, 114, 104236, 1-17. DOI: 10.1016/j.marpetgeo.2020.104236 Lafargue, E., Marquis, F., Pillot, D., 1998. Rock-Eval 6 Applications in Hydrocarbon Exploration, Production, and Soil Contamination Studies. OGST, Rev. IFP, Volume 53, 4, 421 - 437. DOI: 10.2516/ogst:1998036

Lazar, O.R., Bohacs, K.M., Macquaker, J.H.S., Schieber, J., Demko, T.M., 2015. Capturing key attributes of fine-grained sedimentary rocks in outcrops, cores, and thin sections: nomenclature and description guidelines. Journal of Sedimentary Research, 2015, v. 85, 230-246. DOI: http://dx.doi.org/10.2110/isr.2015.11

Laubach, S.E., 2003. Practical approaches to identifying sealed and open fractures. AAPG Bulletin 87 (4), 561-579.

Mangenot, X., Bonifacie, M., Gasparrini, M., Götz, A., Ader M., Rouchon, V., 2017. Coupling $\Delta_{47}$ and fluid inclusion thermometry on carbonate cements to precisely reconstruct the temperature, 
salinity and $\delta^{18} \mathrm{O}$ of paleo-groundwater in sedimentary basins. Chemical Geology, 472: 44-57. DOI: 10.1016/j.chemgeo.2017.10.011

Mangenot, X., Gasparrini, M., Gerdes, A., Bonifacie, M., Rouchon, V., 2018. An emerging thermo-chronometer for carbonate bearing-rocks: $\Delta_{47} /(\mathrm{U}-\mathrm{Pb})$. Geology, 46, 12: 1067-1070. DOI: $10.1130 / G 45196.1$

Marquez, X. M., Mountjoy E.W., 1996, Microcracks due to overpressures caused by thermal cracking in well-sealed Upper Devonian reservoirs, deep Alberta basin. AAPG Bulletin, 80, 570-588. McCaig, A.M., Knipe, R.J., 1990. Mass-transport mechanisms in deforming rocks: Recognition using microstructural and microchemical criteria. Geology, 18, 824- 827.

McKean S.H., Priest J.A., 2019. Multiple failure state triaxial testing of the Montney Formation. Journal of Petroleum Science and Engineering 173, 122-135

Mclimans, R.K., 1987. The application of fluid inclusions to migration of oil and diagenesis in petroleum reservoirs. Applied Geochemistry, 2(5-6), 585-603.

Meng, Q., Hooker, J.N., Cartwright, J., 2017. Early overpressuring in organic-rich shales during burial: evidence from fibrous calcite veins in the Lower Jurassic Shales-with-Beef Member in the Wessex Basin, UK. J. Geol. Soc. Lond.

Miall, A.D., Catuneanu, O., Vakarelov, B.K., Post, R., 2008. The Western Interior Basin. In Miall, A.D., ed., The Sedimentary Basins of the United States and Canada. Sedimentary Basins of the World 5: Amsterdam, Netherlands, Elsevier Science, 329-362. DOI: 10.1016/S1874-5997(08)00009-9

Morad, S., Ketzer, J.M., De Ros, L.F., 2002. Spatial and temporal distribution of diagenetic alterations in siliclastic rocks: Implications for mass transfer in sedimentary basins. Sedimentology, 47(1), $95-120$. DOI: 10.1046/j.1365-3091.2000.00007.x

Moslow, T.F., 2000. Reservoir architecture of a fine-grained turbidite system: Lower Triassic Montney Formation, Western Canada Sedimentary Basin. In Deep-water Reservoirs of the World, Conference Proceedings, Gulf Coast, SEPM. P. Weimer, RM Slatt, J. Coleman, NC Rosen, H. Nelson, AH Bouma, MJ Styzen, and DT Lawrence (eds.), 686-713. 
Moslow, T.F., Adams, M.G., Terzuoli, T., 2016. Bioclastic Reservoirs of the Distal Montney

"Shale" Play. AAPG 2016 Annual Convention and Exhibition, Calgary, Alberta, Canada, June 16-22, 2016. AAPG Search and Discovery Article \#80548, 13 p.

Moslow, T.F., Haverslew, B., Henderson, C.M., 2018. Sedimentary facies, petrology, reservoir characteristics, conodont biostratigraphy and sequence stratigraphic framework of a continuous (395m) full diameter core of the Lower Triassic Montney Fm., northeastern British Columbia, in T. Euzen, T.F. Moslow and M. Caplan, eds., The Montney Play: Deposition to Development. Bulletin of Canadian Petroleum Geology, 66(1), 259-287.

Mossop, G.D., Shetsen, I., 1994. Geological atlas of the Western Canada Sedimentary Basin. Canadian Society of Petroleum Geologists and Alberta Research Council, http://ags.aer.ca/reports/atlas-of-the-western-canada-sedimentary-basin.htm

Ness, S.M., 2001, The application of basin analysis to the Triassic succession, Alberta Basin: An investigation of burial and thermal history and evolution of hydrocarbons in Triassic rocks. M. Sc. Thesis: Calgary, Alberta, University of Calgary, 179 p. http://dspace.ucalgary.ca/handle/1880/40896 O'Neil, J.R., 1969. Equilibrium and nonequilibrium oxygen isotope effects in synthetic carbonates. Geochimica et Cosmochimica Acta, 61, 3461-3475.

Ozkaya, I., 1988, A simple analysis of oil-induced fracturing in sedimentary rocks. Marine and Petroleum Geology, 5, 3, 293-297.

Orchard, M.J., Zonneveld, J.P., 2009. The Lower Triassic Sulphur Mountain Formation in the Wapiti Lake area: lithostratigraphy, conodont biostratigraphy, and a new biozonation for the lower Olenekian (Smithian) Earth Science Sector (ESS) Contribution 20080714. Canadian Journal of Earth Sciences, 46(10), 757-790.

Pană D.I., van der Pluijm B.A., 2015. Orogenic pulses in the Alberta Rocky Mountains: Radiometric dating of major faults and comparison with the regional tectono-stratigraphic record. GSA Bulletin, 127 (3-4): 480-502. 
Parrish, R.R., Parrish, C.M., Lasalle, S., 2018, Vein calcite dating reveals Pyrenean orogen as

cause of Paleogene deformation in southern England. Journal of the Geological Society, 175, 425-442

Peacock, D.C.P., Mann, A., 2005. Evaluation of the controls on fracturing in reservoir rocks. Journal of Petroleum Geology, 28(4), 385-396.

Pei, P., Ling, K., Hou, X., Nordeng, S., Johnson, S., 2016. Brittleness investigation of producing units in Three Forks and Bakken formations, Williston basin. Journal of Natural Gas Science and Engineering, 32, 512-520.

Pei, P., He, J., Ling, K., 2014. Correlating Geomechanical Properties of the Bakken Formation Rocks with Lithofacies and Sequence. In 48th US Rock Mechanics/Geomechanics Symposium. American Rock Mechanics Association.

Peirce J.W, Cordsen A., Glenn T., 2001. The Great Slave Lake Shear Zone-implications for Exploration in NW Alberta and NE British Columbia. Canadian Society of Exploration Geophysicists Convention.

Peng., J., Milliken, K.M., Qilong, F., 2020. Quartz types in the Upper Pennsylvanian organic-rich Cline Shale (Wolfcamp D), Midland Basin, Texas: Implications for silica diagenesis, porosity evolution and rock mechanical properties. Sedimentology, 67: 2040-2064. DOI: 10.1111/sed.12694

Perez, R., Marfurt, K., 2013. Calibration of Brittleness to elastic rock properties via mineralogy logs in unconventional reservoirs. International Conference and Exhibition of American Association of Petroleum Geologists (AAPG), Cartagena, Sept. 8-11, Article \#41237.

Pillot D., Letort G., Romero-Sarmiento M.F., Lamoureux-Var V., Beaumont V., Garcia B., 2014.

Procédé pour l'évaluation d'au moins une caractéristique pétrolière d'un échantillon de roche. Patent 14/55.009.

Playter, T., Corlett, H., Konhauser, K., Robbins, L., Rohais, S., Crombez, V., Maccormack, K., Rokosh, D., Prenoslo, D., Furlong, C.M., Pawlowicz, J., Gingras, M., Lalonde, S., Lyster, S.N., Zonneveld, J.P., 2018. Clinoform identification and correlation in fine-grained sediments: A case 


\section{Journal Pre-proof}

study using the Triassic Montney Formation. Sedimentology, 65(1), 263-302. DOI :

\section{$10.1111 /$ sed.12403}

Price, R.A., 1994, Cordilleran tectonics and the evolution of the Western Canada sedimentary basin, in Mossop, G., and Shetsen, I., compilers, Geological Atlas of the Western Canada Sedimentary Basin. Canadian Society of Petroleum Geologists and Alberta Research Council, 13-24.

Quesnel, B., Boulvais, P., Gautier, P., Cathelineau, M., John, C., M., Dierick, M., Agrinier, P., Drouillet, M., 2016. Paired stable isotopes (O, C) and clumped isotopethermometry of magnesite and silica veins in theNew Caledonia Peridotite Nappe. Geochimica et Cosmochimica Acta, 183, 234-249. Ramsay, J.G., 1980. The crack-seal mechanism of rock deformation. Nature 284, 135- 139.

Riazi, N., Clarkson, C.R., Ghanizadeh, A., Vahedian, A., Aquino, S., Wood, J.M., 2017. Determination of elastic properties of tight rocks from ultrasonic measurements: Examples from the Montney Formation (Alberta,Canada). Fuel, 196, 442-457

Riediger, C.L., Brooks, P.W., Fowler, M.G., Snowdon, L.R., 1990a. Lower and Middle Triassic source rocks, thermal maturation, and oil-source rock correlations in the Peace River Embayment area, Alberta and British Columbia. Bull. Can. Petrol. Geol., 38A, 218-235.

Riediger, C.L., Fowler, M.G., Brooks, P.W., Snowdon, L.R., 1990b. Triassic oils and potential Mesozoic source rocks, Peace River Arch area, Western Canada Basin. Org. Geochem., 16, 295-305. Riediger, C. L., 1997, Geochemistry of potential hydrocarbon source rocks of Triassic age in the Rocky Mountain Foothills of northeastern British Columbia and west-central Alberta. Bull. Can. Petrol. Geol., 45(4), 719-741.

Rijken, P., Cooke, M. L., 2001. Role of shale thickness on vertical connectivity of fractures: application of crack-bridging theory to the Austin Chalk, Texas. Tectonophysics, 337(1-2), 117-133.

Rohais, S., Crombez, V., Euzen, T., Zonneveld, J.-P., 2018. Subsidence dynamics of the Montney Formation (Early Triassic, Western Canada Sedimentary Basin): insights for its geodynamic setting and wider implications. In: Euzen, T., Moslow, T.F. \& Caplan, M. (eds) The Montney Play of Western Canada: Deposition to Development. Bulletin of Canadian Petroleum Geology, 66, 128-160. 
Romero-Sarmiento, M.F, Ducros, M., Carpentier, B., Lorant, F., Cacas, M.-C., Pegaz-Fiornet, S.,

Wolf, S., Rohais, S., Moretti, I., 2013. Quantitative evaluation of TOC, organic porosity and gas retention distribution in a gas shale play using petroleum system modeling: Application to the

Romero-Sarmiento, M.F., Pillot, D., Letort, G., Lamoureux-Var, V., Beaumont, V., Huc, A. Y.,

Garcia, B., 2016a. New Rock-Eval method for characterization of unconventional shale resource

DOI: 10.1016/j.orggeochem.2016.05.002

Roure, F., Swennen, R., Schneider, F., Faure, J. L., Ferket, H., Guilhaumou, N., Osadetz, K.,

Robion, P., Vandeginste, V., 2005. Incidence and Importance of Tectonics and Natural Fluid Migration on Reservoir Evolution in Foreland Fold-And-Thrust Belts. Oil \& Gas Science and Technology - Revue de I'IFP 60(60): 67-106. DOI: 10.2516/ogst:2005006

Roure, F., Callot, J.P., Faure, J.L., Ferket, H., Gonzales, E., Guilhaumou, N., Lacombe, O.,

Malandain, J., Sassi, W., Schneider, F., Swennen, R., Vilasi, N., 2010. The use of palaeo-thermobarometers and coupled thermal, fluid flow and pore-fluid pressure modeling for hydrocarbon and 87-114.

Rybacki, E., Reinicke, A., Meier, T., Makasi, M., Dresen, G., 2015. What controls the mechanical properties of shale rocks?-Part I: Strength and Young's modulus. Journal of Petroleum Science and Engineering, 135, 702-722. rocks?-Part II: Brittleness. Journal of Petroleum Science and Engineering, 144, 39-58. 
organic matter fractions in an unconventional tight gas siltstone reservoir. Int. J. Coal Geol., 150, 296-305. Mountain region. AAPG Bulletin, 71, 368-388.

Swart, P., 2015. The geochemistry of carbonate diagenesis: The past, present and future. deformation pattern templates in foreland basin systems and fold-and-thrust belts: Implications for the state of stress in the frontal regions of thrust wedges. Earth-Science Reviews, 141, 82-104 129(11/12), 1622-1635.

Ukar, E., Lopez, R.G., Gale, J.F.W., Laubach, S.E., Manceda, R., 2017. New type of kinematic indicator in bed-parallel veins, Late JurassiceEarly Cretaceous Vaca Muerta Formation, Argentina: E- 
Vaisblat, N., Ayranci, K., Harris, N., 2017a. Is siltstone geomechanics on the mixing line

between sandstone and shale? Example from the Western Canada Sedimentary Basin Montney Formation. In AAPG Annual Convention and Exhibition.

Vaisblat, N., Harris, N. B., DeBhur, C., Euzen, T., Gasparrini, M., Crombez, V., Ayranci, K., 2017b. Diagenetic Model for the Deep Montney Formation, Northeastern British Columbia. Geoscience BC Summary of Activities 2016, 2017-1.

Vaisblat, N., Rangriz Shokri, A., Ayranci, K., Harris, N., Chalaturnyk, R. J., 2019. Significance of Rock Compositional Control on Geomechanical Properties and Hydraulic Fracturing of the Montney Formation, Western Canadian Basin. Unconventional Resources Technology Conference. DOI:10.15530/AP-URTEC-2019-198199

Vaisblat, N., 2020. Controls on Reservoir Quality in the Lower Triassic Montney Formation. PhD thesis, University of Alberta (Canada), 286 p.

Van de Kamp, P.C., 2008. Smectite-illite-muscovite transformations, quartz dissolution, and silica release in shales. Clays. Clay. Miner. 56, 66-81.

Van den Kerkhof, A., Thiery, R., 2001. Carbonic inclusions. Lithos, 55(1), 49-68.

Veizer, J., Ala, D., Azmy, K., Bruckschen, P., Buhl, D., Bruhn, F., Jasper, T., 1999. ${ }^{87} \mathrm{Sr} /{ }^{86} \mathrm{Sr}, \delta^{13} \mathrm{C}$ and $\delta^{18} \mathrm{O}$ evolution of Phanerozoic seawater. Chemical Geology, 161(1), 59-88.

Vernik, L., 1994. Hydrocarbon-generation-induced microcracking of source rocks. Geophysics, $59,4,555-563$.

Vishkai M., Wang J., Wong R.C.K., Clarkson, C.R., Gates I.D., 2017. Modeling geomechanical properties in the Montney Formation, Alberta, Canada. International Journal of Rock Mechanics \& Mining Sciences 96, 94-105.

Wang, R., Ding, W., Zhang, Y., Wang, Z., Wang, X., He, J., Zeng, W., Dai, P., 2016. Analysis of developmental characteristics and dominant factors of fractures in Lower Cambrian marine shale reservoirs: A case study of Niutitang formation in Cen'gong block, southern China. Journal of Petroleum Science and Engineering, 138, 31-49. DOI: 10.1016/j.petrol.2015.12.004 
Wang, X., Wang, R., Ding, W., Yin, S., Sun, Y., Zhou, X., Li, Q., 2017. Development characteristics

and dominant factors of fractures and their significance for shale reservoirs: A case study from $€ 1 \mathrm{~b} 2$

in the Cen'gong block, southern China. Journal of Petroleum Science and Engineering, 159, 988-999.

Wang, F.P., Gale, J.F.W., 2009. Screening criteria for shale-gas systems. Gulf Coast Assoc. Geol.

Soc. Trans. 59, 779-793.

1570

Wood, J.M., Sanei, H., Curtis, M.E., Clarkson, C.R., 2015. Solid bitumen as a determinant of

1571

1572

1573

1574

1575

1576

1577

1578

1579

1580

1581

1582

1583

1584

1585

1586

1587

1588

1589

reservoir quality in an unconventional tight gas siltstone play. Int. J. Coal Geol. 150, 287-295.

Wood, J.M., Ardakani, O.H., Sanei, H., Curtis, M.E., Royer, D., 2020. Application of paleoporosity and bitumen saturation concepts to tight-gas accumulations containing solid bitumen. International Journal of Coal Geology, 228, 103547

Woodcock, N. H., Dickson, J. A. D., Tarasewicz, J. P. T., 2007. Transient permeability and reseal hardening in fault zones: evidence from dilation breccia textures. Geological Society, London, Special Publications, 270(1), 43-53.

Wright, G.N., Mcmechan, M.E., Potter, D.E.G., 1994. Structure and Architecture of the Western Canada Sedimentary Basin. In: Mossop GD, Shetsen I, eds. Geological Atlas of the Western Canada Sedimentary Basin. CSPG and Alberta Research Council, 25-40

Yasin, Q., Du, Q., Sohail, G. M., Ismail, A., 2017. Impact of organic contents and brittleness indices to differentiate the brittle-ductile transitional zone in shale gas reservoir. Geosciences Journal, 21(5), 779-789.

Zanella, A., Cobbold, P.R., Rojas, L., 2014. Beef veins and thrust detachments in Early Cretaceous source rocks, foothills of Magallanes-Austral Basin, southern Chile and Argentina: Structural evidence for fluid overpressure during hydrocarbon maturation.

Zeng, W., Zhang, J., Ding, W., Zhao, S., Zhang, Y., Liu, Z., Jiu, K., 2013. Fracture development in Paleozoic shale of Chongqing area (South China). Part one: Fracture characteristics and comparative analysis of main controlling factors. Journal of Asian Earth Sciences, 75, 251-266. 


\section{Journal Pre-proof}

Zonneveld, J.P., Moslow, T.F., Henderson, C.M., 1997. Lithofacies associations and depositional

1591 environments in a mixed siliciclastic-carbonate coastal depositional system, upper Liard Formation,

1592 Triassic, northeastern British Columbia. Bulletin of Canadian Petroleum Geology, 45(4), 553-575.

1593 Zonneveld, J.P., Gingras, M.K., Pemberton, S.G., 2001. Trace fossil assemblages in a Middle

1594 Triassic mixed siliciclastic-carbonate marginal marine depositional system, British Columbia. 1595 Palaeogeography, Palaeoclimatology, Palaeoecology, 166(3-4), 249-276.

Zonneveld, J.P., Moslow, T.F., 2018. Palaeogeographic setting, lithostratigraphy, and

1597 sedimentary framework of the Lower Triassic Montney Formation of western Alberta and northeastern British Columbia. Bulletin of Canadian Petroleum Geology, 66(1), 93-127. 


\begin{tabular}{|c|c|c|c|c|c|}
\hline FACIES ASSOCIATION & Code & \multicolumn{2}{|l|}{ SEQUENCE } & TOC & Code \\
\hline Lag & 1 & Sequence 1 & 1 & $<1$ & 1 \\
\hline Massive fine-grained sandstones & 2 & Sequence 2 & 2 & between 1 and 2 & 2 \\
\hline Massive vf-grained ss. to siltstones & 3 & Sequence 3 & 3 & between 2 and 3 & 3 \\
\hline Sand-dominated alternation & 4 & Sequence 4 & 4 & between 3 and 4 & 4 \\
\hline Silt-dominated alternation & 5 & & & between 4 and 5 & 5 \\
\hline Massive siltstones & 6 & ENVIRONMENT & Code & between 5 and 11 & 6 \\
\hline Organic-rich siltstones & 7 & & & & \\
\hline Bioclastic siltstones & 8 & Lag & 1 & FRACTURE & Code \\
\hline Laminated siltstones (turbidite) & 9 & Shoreface & 2 & & \\
\hline \multirow[t]{3}{*}{ Laminated siltstones } & 10 & Offshore transition & 3 & no fracture & \\
\hline & & Offshore & 4 & horizontal & 2 \\
\hline & & & & vertical to high angle & 3 \\
\hline
\end{tabular}

Table 1 


\begin{tabular}{|c|c|c|c|c|c|c|c|c|}
\hline \multirow{3}{*}{$\begin{array}{l}\text { Stratigraphic } \\
\text { sequence }\end{array}$} & \multicolumn{4}{|c|}{ Core 16-17 } & \multicolumn{4}{|c|}{ Core 12-36 } \\
\hline & \multicolumn{2}{|c|}{ TOC $(\%)$} & \multicolumn{2}{|c|}{ HI (mgHI/gTOC) } & \multicolumn{2}{|c|}{ TOC $(\%)$} & \multicolumn{2}{|c|}{ HI (mgHI/gTOC) } \\
\hline & $\overline{\text { range }}$ & $\overline{\text { mean }}$ & range & mean & $\overline{\text { range }}$ & $\overline{\text { mean }}$ & range & mean \\
\hline 4 & $1.1-6.6$ & 3.7 & $11.0-27.0$ & 19.3 & - & - & - & - \\
\hline 3 & $1.3-1.4$ & 1.3 & $14.0-15.0$ & 14.5 & $1.4-3.3$ & 2.2 & $29.0-39.0$ & 34.0 \\
\hline 2 & $0.8-1.6$ & 1.2 & $8.0-10.0$ & 9.0 & $0.9-2.5$ & 1.2 & $16.0-24.0$ & 20.0 \\
\hline 1 & $0.8-3.3$ & 1.6 & $5.0-9.0$ & 7.3 & $0.6-3.3$ & 1.5 & $9.0-23.0$ & 14.7 \\
\hline
\end{tabular}

Table 2 


\begin{tabular}{|c|c|c|c|c|c|c|c|c|c|c|c|c|c|}
\hline \multirow[t]{2}{*}{ Sample } & \multirow{2}{*}{$\begin{array}{l}\text { Vein } \\
\text { orientation }\end{array}$} & \multirow{2}{*}{$\begin{array}{l}\text { Mineral phase/ } \\
\text { texture }\end{array}$} & \multirow[t]{2}{*}{ FI type } & \multirow[t]{2}{*}{ Occurrence } & \multirow{2}{*}{$\begin{array}{l}\text { Fluid } \\
\text { phases }\end{array}$} & \multirow[t]{2}{*}{$\mathbf{F}$} & \multirow{2}{*}{$\begin{array}{l}\text { UV-light } \\
\text { response }\end{array}$} & \multicolumn{2}{|l|}{ Th $\left({ }^{\circ} \mathbf{C}\right)$} & \multicolumn{2}{|l|}{$\mathbf{T m}_{\mathrm{i}}\left({ }^{\circ} \mathbf{C}\right)$} & \multicolumn{2}{|c|}{ Salinity (eq. $\mathrm{NaCl}$ wt\%) } \\
\hline & & & & & & & & range & mode $(n)$ & range & $\operatorname{mode}(n)$ & range & mode $(n)$ \\
\hline $1617-23$ & vertical & $\begin{array}{l}\text { calcite/ } \\
\text { blocky }\end{array}$ & I & $\mathrm{C} / \mathrm{T} / \mathrm{I}$ & $\mathrm{L}+\mathrm{V}$ & $0.89-0.95$ & none & $78.0 / 118.0$ & $101(50)$ & $-16.0 /-19.3$ & $-16.5(15)$ & $19.4 / 21.9$ & $19.8(15)$ \\
\hline $1617-23$ & vertical & $\begin{array}{l}\text { calcite/ } \\
\text { blocky }\end{array}$ & II & $\mathrm{C} / \mathrm{I}$ & $\mathrm{O}+\mathrm{G}$ & $0.85 / 0.90$ & green & $36.5 / 45.0$ & $41.5(13)$ & - & - & - & - \\
\hline $1617-23$ & vertical & $\begin{array}{l}\text { calcite/ } \\
\text { blocky }\end{array}$ & III & $\mathrm{T}$ & $\mathrm{O}$ & 1 & green & - & - & - & - & - & - \\
\hline $1617-12$ & horizontal & $\begin{array}{l}\text { calcite/ } \\
\text { blocky }\end{array}$ & III & $\mathrm{C} / \mathrm{I} / \mathrm{T}$ & $\mathrm{O}$ & 1 & green & & - & - & - & - & - \\
\hline $1617-12$ & horizontal & $\begin{array}{l}\text { calcite/ } \\
\text { blocky }\end{array}$ & IV & $\mathrm{C} / \mathrm{T}$ & $\begin{array}{l}\mathrm{L} \\
\left(\mathrm{CH}_{4} \pm \mathrm{CO}_{2}\right)\end{array}$ & 1 & $\begin{array}{l}\text { yellow/green } \\
\text { /none }\end{array}$ & & - & - & - & - & - \\
\hline $\mathrm{C} 2-1236-2 \mathrm{~B}$ & horizontal & $\begin{array}{l}\text { calcite/ } \\
\text { elongated blocky }\end{array}$ & IV & $\mathrm{C} / \mathrm{I}$ & $\begin{array}{l}\mathrm{L} \\
\left(\mathrm{CH}_{4} \pm \mathrm{CO}_{2}\right)\end{array}$ & 1 & $\begin{array}{l}\text { yellow/green } \\
\text { none }\end{array}$ & $-69.0 /-76.0$ & $-70(10)$ & - & - & - & - \\
\hline $\mathrm{C} 2-1236-2 \mathrm{~B}$ & horizontal & $\begin{array}{l}\text { calcite/ } \\
\text { blocky }\end{array}$ & III & $\mathrm{C} / \mathrm{T} / \mathrm{I}$ & $\mathrm{O}$ & 1 & green & - & - & - & - & - & - \\
\hline $\mathrm{C} 2-1236-2 \mathrm{~B}$ & vertical & $\begin{array}{l}\text { calcite/ } \\
\text { blocky }\end{array}$ & III & $\mathrm{C} / \mathrm{T} / \mathrm{I}$ & $\mathrm{O}$ & 1 & green & - & - & - & - & - & - \\
\hline C2-1236-2B & vertical & $\begin{array}{l}\text { calcite/ } \\
\text { blocky }\end{array}$ & IV & $\mathrm{C} / \mathrm{T}$ & $\begin{array}{l}\mathrm{L} \\
\left(\mathrm{CH}_{4} \pm \mathrm{CO}_{2}\right)\end{array}$ & 1 & $\begin{array}{l}\text { green/yellow } \\
\text { none }\end{array}$ & $-62.0 /-74.0$ & $-69(8)$ & - & - & - & - \\
\hline C1-1236-4 & horizontal & $\begin{array}{l}\text { calcite/ } \\
\text { elongated blocky }\end{array}$ & II & $\mathrm{Z} / \mathrm{C}$ & $\mathrm{O}$ & $0.80 / 0.92$ & green & $24.0 / 58.0$ & $31(39)$ & - & - & - & - \\
\hline C1-1236-4 & horizontal & $\begin{array}{l}\text { calcite/ } \\
\text { elongated blocky }\end{array}$ & IV & $\mathrm{Z} / \mathrm{C}$ & $\mathrm{L}$ & 1 & none & $-66.0 /-71.0$ & $-70(9)$ & - & - & - & - \\
\hline
\end{tabular}

\section{Table 3}



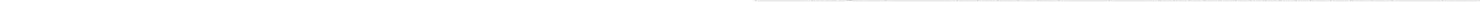


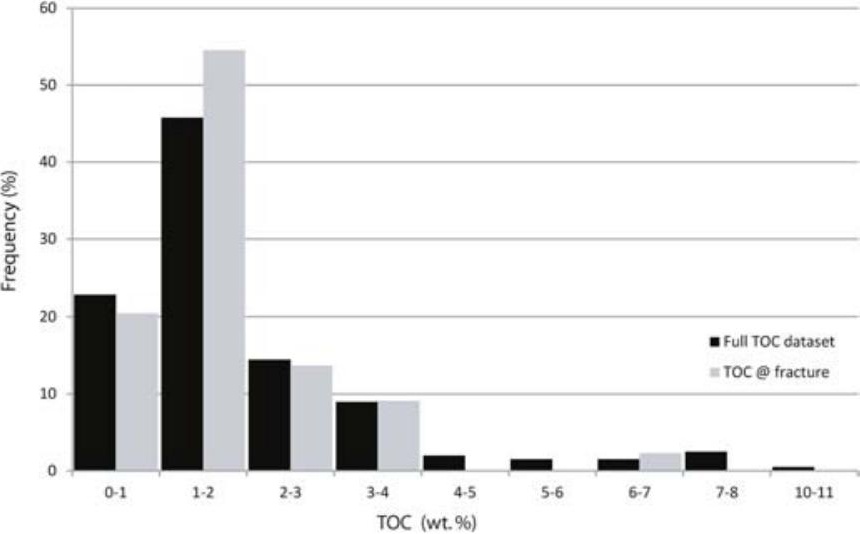




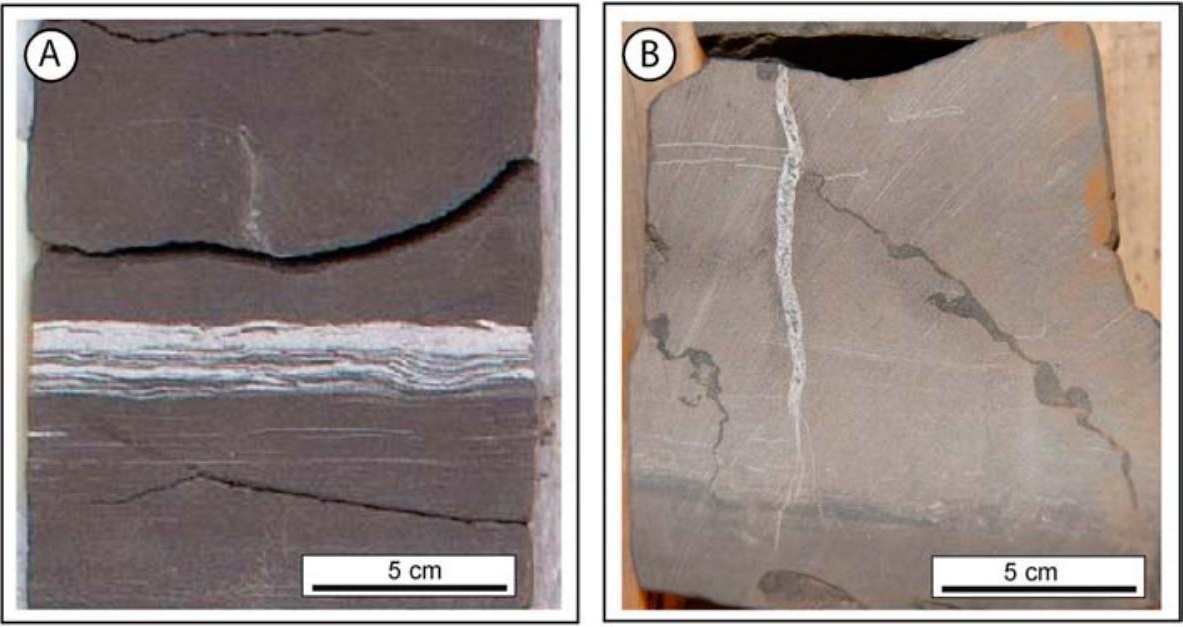



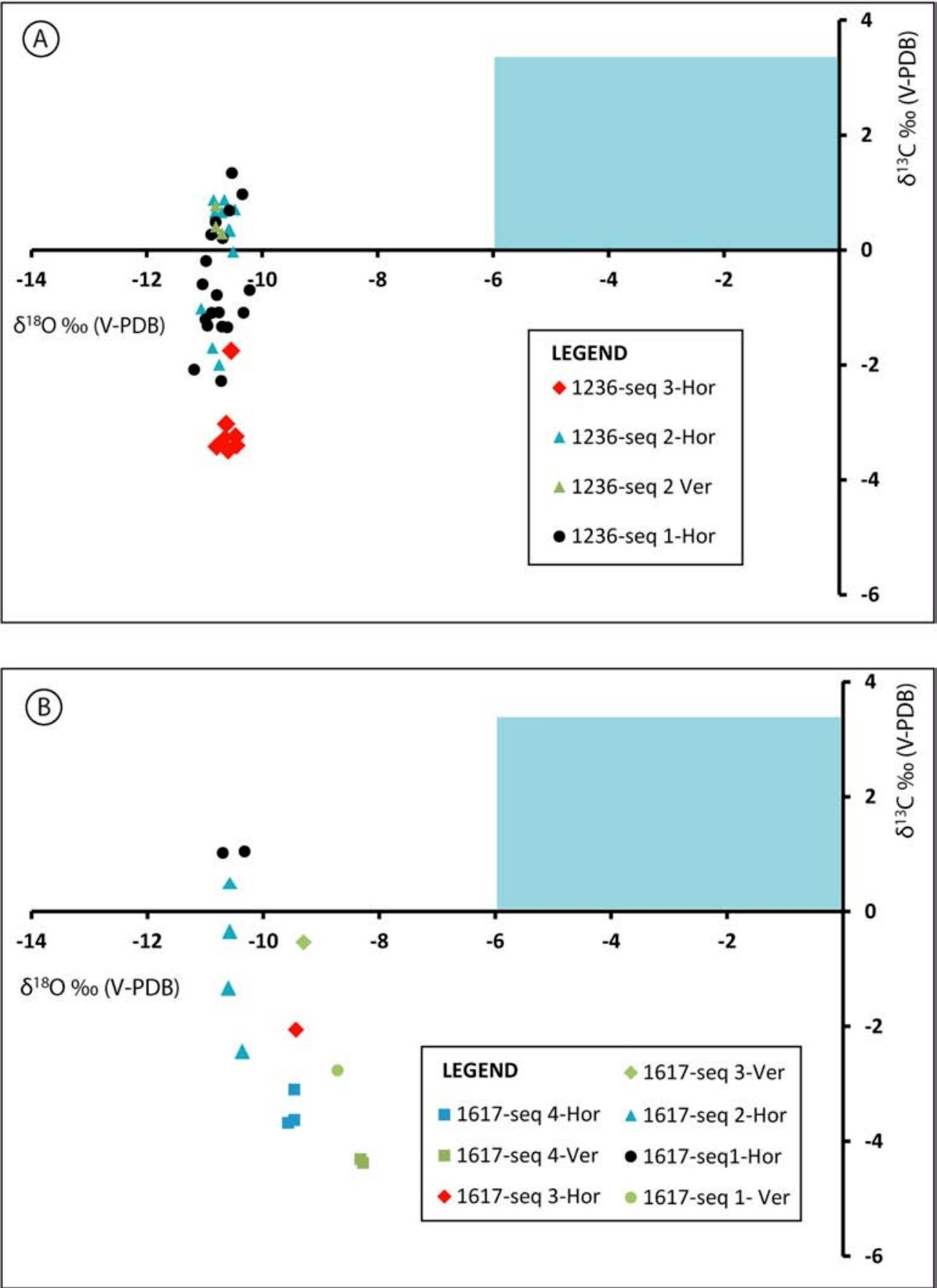

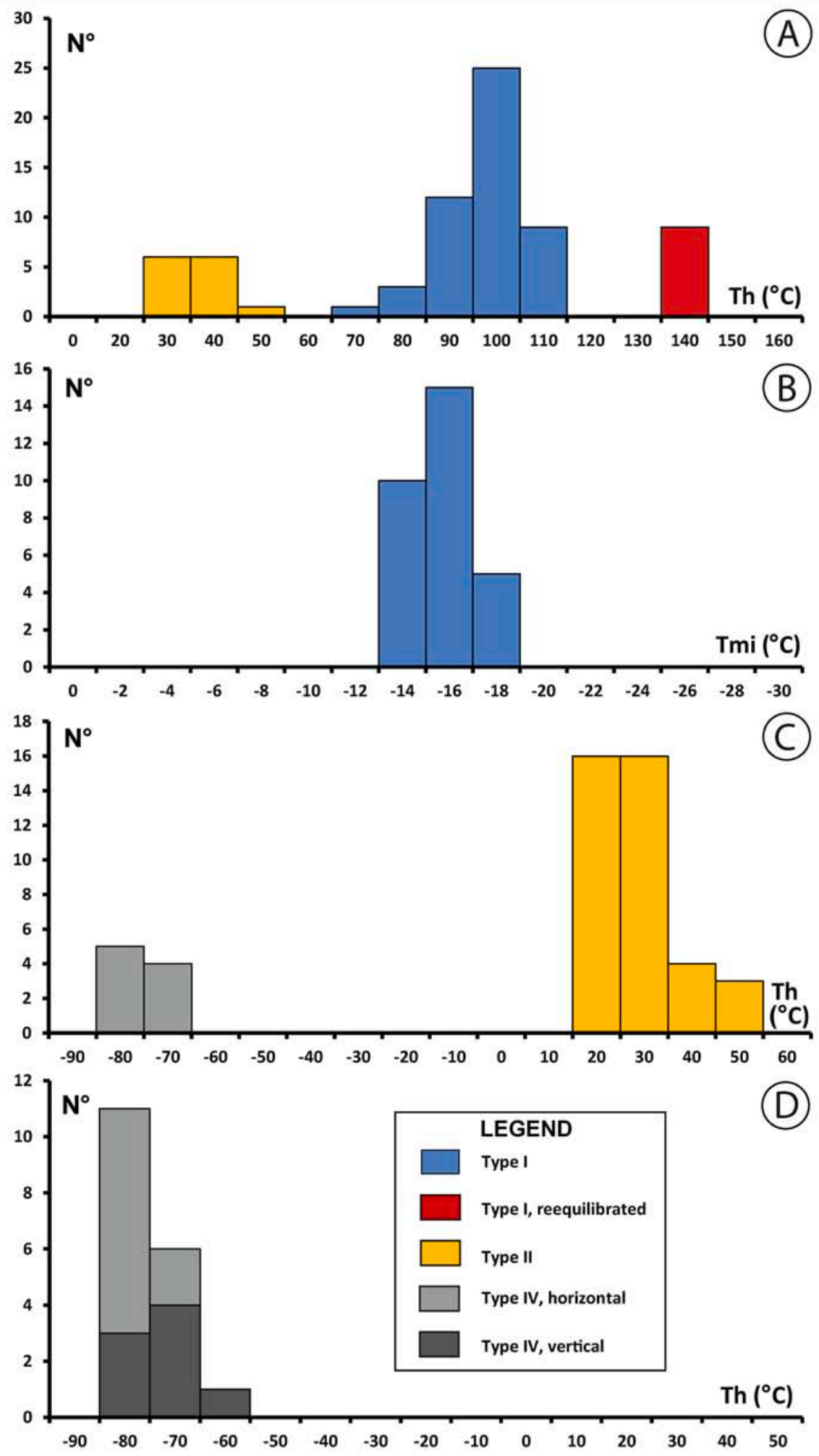
Horizontal Vertical Depth Quartz K-feldspar + PI Clays + Mica Calcite + Dolomite FACIES ASSOCIATION ENVIRONMENT Fracture Fracture

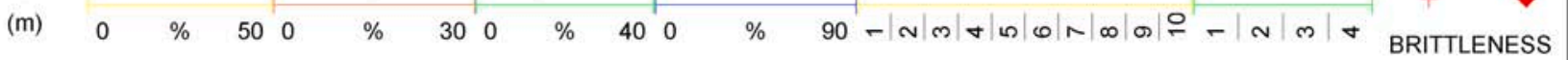
"soft" "hard"
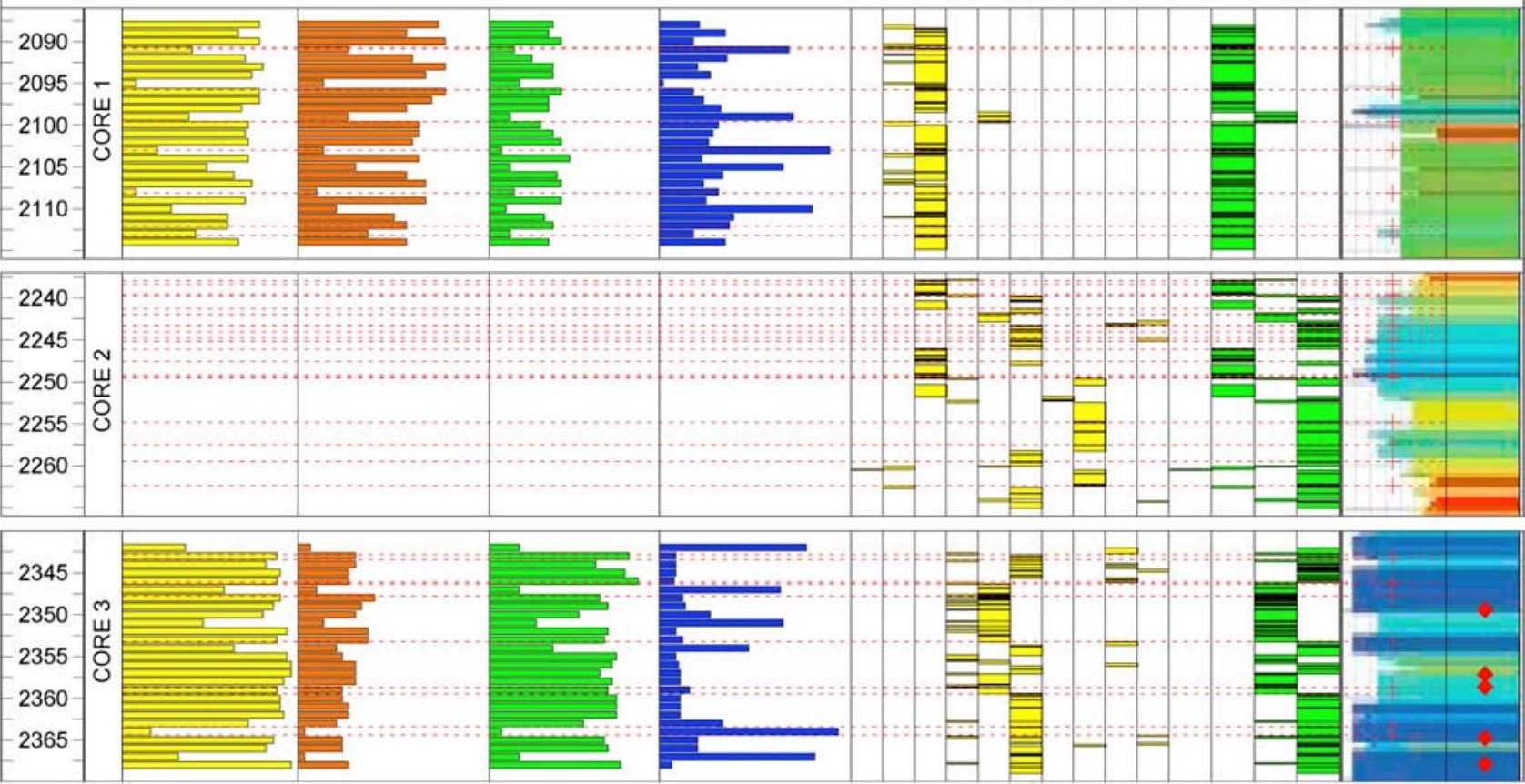
Time (Ma)

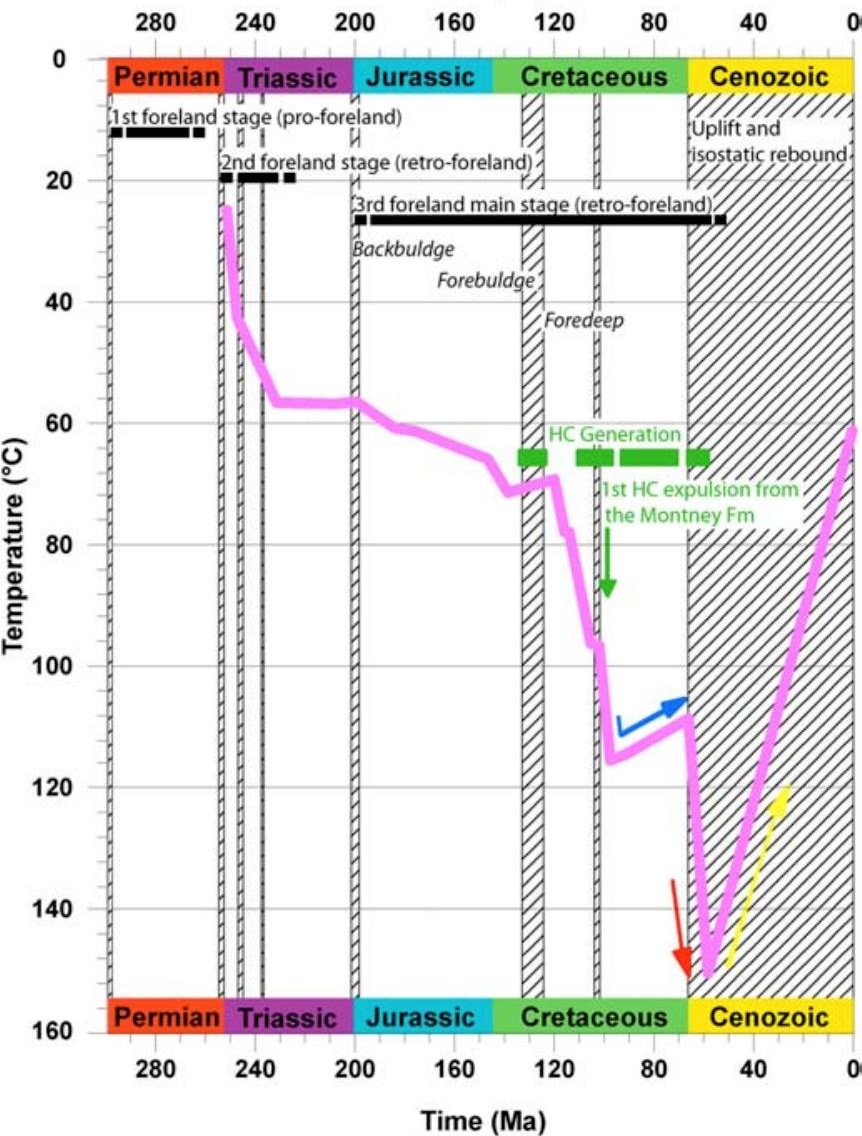




\section{Highlights}

- Fracture diagenesis of Montney-Doig Fms in sub-surface cores was characterized

- Lithology-related factors controlled fracture occurrence

- Timing of fracture opening and role of circulating paleo-fluids were constrained

- The Montney-Doig Fms behaved like a closed hydraulic system through time 


\section{Declaration of interests}

$\bigotimes$ The authors declare that they have no known competing financial interests or personal relationships that could have appeared to influence the work reported in this paper.

$\square$ The authors declare the following financial interests/personal relationships which may be considered as potential competing interests:

Marta Gasparrini

Olivier Lacombe

Sébastien Rohais

Moh Belkacemi

Tristan Euzen 